Board of Governors of the Federal Reserve System

International Finance Discussion Papers

Number 686

November 2000

FIRMS AND THEIR DISTRESSED BANKS:

LESSONS FROM THE NORWEGIAN BANKING CRISIS (1988-1991)

Steven Ongena, David C. Smith, and Dag Michalsen

NOTE: International Finance Discussion Papers are preliminary materials circulated to stimulate discussion and critical comment. References to International Finance Discussion Papers (other than an acknowledgment that the writer has had access to unpublished material) should be cleared with the author or authors. Recent IFDPs are available on the Web at www.bog.frb.fed.us. 


\title{
Firms and their Distressed Banks: \\ Lessons from the Norwegian Banking Crisis (1988-1991)
}

\author{
Steven Ongena, David C. Smith, and Dag Michalsen*
}

\begin{abstract}
We use the near-collapse of the Norwegian banking system during the period 1988-91 to measure the impact of bank distress announcements on the stock prices of firms maintaining a relationship with a distressed bank. We find that although banks experienced large and permanent downward revisions in their equity value during the event period, firms maintaining relationships with these banks faced only small and temporary changes, on average, in stock price. In other words, the aggregate impact of bank distress on listed firms in Norway appears small. Our results stand in contrast to studies that document large welfare declines to similar borrowers after crises hit Japan and other East Asian countries. We hypothesize that because banks in Norway are precluded from maintaining significant ownership control over loan customers, Norwegian firms were freer to choose financing from sources other than their distressed banks. We provide cross-sectional evidence to support this hypothesis.
\end{abstract}

Keywords: bank relationship, bank distress, Norwegian banking crisis.

* The authors are from Tilburg University (steven.ongena@kub.nl), the Board of Governors of the Federal Reserve System (david.c.smith@frb.gov) and the Norwegian School of Management (dag.michalsen@bi.no), respectively. The views in this paper are solely the responsibility of the authors and should not be interpreted as reflecting the views of the Board of Governors of the Federal Reserve System or of any other person associated with the Federal Reserve System. We thank Øyvind Bøhren, Doug Breeden, Hans Degryse, Ralf Elsas, Karl Hermann Fisher, Mike Gibson, Jan Pieter Krahnen, Theo Nijman, Richard Priestley, Jay Ritter, Paola Sapienza, Greg Udell, Jan Pierre Zigrand, and participants at the 1999 CEPR Conference on Financial Markets (Gerzensee), 2000 European Economic Association Meetings (Bolzano), 1999 Estes Park Summer Finance Conference, 1999 New Hampshire Spring Finance Conference, 1999 Symposium on Finance, Banking, and Insurance (Karlsruhe), Norges Bank, and the Universities of Amsterdam, Antwerpen, Florida, Freibourg, Frankfurt, Leuven, North-Carolina, Tilburg, and Wisconsin for comments. We are grateful to Bernt Arne Ødegaard and Øyvind Norli for supplying Norwegian data, and Andy Naranjo for providing us with data from Datastream. Ongena thanks the Center for Financial Studies in Frankfurt for their hospitality and the Fund for Economic Research at Norges Bank. 


\section{Introduction}

Many economists maintain that large-scale interruptions in bank lending activities can propagate negative shocks to the real sector. For example, Bernanke (1983) argues that the systematic failure of banks exacerbated the decline in the U.S. economy during the Great Depression and Slovin, Sushka and Polonchek (1993) show that firms borrowing from Continental Bank suffered large stock price declines upon its collapse in 1984. More recently, Hoshi and Kashyap (2000), Morck and Nakamura (2000), and Bayoumi (1999) lay at least partial blame for Japan's current economic malaise on system-wide disruptions in bank lending that began in the early 1990s. All of these researchers maintain that market imperfections prevented firms from obtaining valuable financing once their banks became distressed.

A second set of economists view banks as performing functions that are either substitutable or enhanced by capital markets. Some of these researchers, exemplified by Black (1975), Fama (1980), and King and Plosser (1984), see nothing special about the services provided by banks and reason that the causality of any correlation between the health of the banking system and economic activity runs from the real sector to banks. Still others link the importance of banks to the structure of the financial system in general. For instance, Greenspan (1999) suggests that countries most susceptible to banking shocks are those that lack developed capital markets. He reasons that countries with well-developed capital markets insulate borrowers by providing good substitutes when banks stop lending. Similarly, Rajan and Zingales (1998) argue that sufficient competition from capital markets prevents banks from misallocating funds to unprofitable investment projects and mitigates the impact of a financial crisis on the real sector.

To shed some new light on this debate, we investigate the costs of bank distress using the Norwegian banking crisis of 1988-1991 as our laboratory of study. The data compiled for this paper permit us to directly link Norwegian banks to their commercial customers. Using these links, we 
measure the impact of bank distress announcements upon the stock price of firms related to the troubled banks. Our sample covers $90 \%$ of all commercial bank assets, and nearly all exchange-listed firms in Norway. This affords us the opportunity to track the influence of the near-collapse of a banking system on a large segment of the economy. The data also enable us to conduct a controlled test of the direction of causality running between the health of banks and the performance of their customers. The deterioration in bank assets during the crisis resulted primarily from failures of small businesses that are unrelated to the exchange-listed companies in our study, which were relatively healthy at the outset of the crisis.

There are a number of reasons why the Norwegian banking crisis presents an ideal setting for studying the impact of bank distress on firm performance. First, the crisis was systemic and economically significant. During the crisis years, banks representing 95\% of all commercial bank assets in Norway became insolvent, forcing the closure of one bank and the bailout of numerous other financial institutions, including Norway's three largest commercial banks. Bank managers were fired, employees were laid off, and listed banks lost over $80 \%$ of their equity value. Second, banks are a primary source of funds to companies in Norway. Most of the commercial debt in Norway is raised through bank loans, and many firms maintain a relationship with only one bank. This assures that we isolate the impact of bank impairment on each firm's primary, if not only, source of debt financing. ${ }^{1}$ Third, although bankdominated on the credit side, Norway's corporate governance system contrasts starkly with other bankcentered economies such as Japan and Korea that have recently experienced financial crises. In particular, regulatory and legal restrictions in Norway keep significant control rights out of the hands of banks, and tend to favor the protection of minority equity shareholders. ${ }^{2}$ We exploit these differences to gain a better understanding of how the interaction between a country's capital markets and banking system influences the transmission of banking shocks to the real sector. 
Our evidence suggests that announcements of bank distress during the Norwegian banking crisis had little impact on the welfare of firms maintaining relationships with the troubled banks. Figure 1 provides a preview of our results. It compares the stock price performance of a value-weighted portfolio of all firms on the Oslo Stock Exchange (OSE) to the performance of a portfolio containing only OSE bank stocks. During the crisis period, Norwegian bank stocks lost most of their equity value, falling $84 \%$ between 1988 and 1991. But over the same period, the value-weighted portfolio of OSE firms climbed $63 \%$, outpacing the average performance of a value-weighted combination of the US, UK, German, and Japanese stock markets. On an event-by-event basis, our analysis reveals that banks experienced an average cumulative abnormal return (CAR) of $-10.6 \%$ in the three days surrounding their distress announcement and $-11.7 \%$ over a longer, seven- day window. Meanwhile, firms maintaining relationships with these distressed banks experienced an average 3-day CAR of -1.4\% and 7-day CAR of $+1.7 \%$ around the same event dates. We show that these results are insensitive to the choice of benchmark, averaging method, and various other empirical robustness tests.

Our findings differ markedly from studies that use similar data from Japan or other East Asian countries. For instance, using data sampled during the early stages of the Japanese financial crisis, Gibson $(1995,1997)$ finds that publicly-listed firms with ties to lower-rated banks spent less on investment than firms associated with higher-rated banks. Similarly, Kang and Stulz (2000) show that Japanese firms dependent on bank financing just prior to the onset of the Japanese financial crisis experienced stock returns during the first three years of the crisis that were $26 \%$ lower than otherwise similar firms that were not dependent on bank financing. In a set of studies similar in spirit to ours, Yamori and Murakami (1999) report that the announcement in 1997 of the failure of Hokkaido Takusyoku, a large Japanese city bank, resulted in an average 3-day CAR of -6.6\% for firms listing the failed institution as their main bank; Bae, Kang, and Lim (2000) show that announcements by Korean banks of credit downgrades during the East Asian crisis resulted in an average 3-day CAR of $-4.4 \%$ for 
firms borrowing from the distressed banks; and Djankov, Jindra, and Klapper (2000) demonstrate that announcements in Indonesia, Korea, and Thailand of bank closures during the East Asian crisis resulted in borrower abnormal returns of $-3.9 \% .^{3}$

One potential explanation for the disparity in results is that the Norwegian equity market insulated companies from shocks to the banking system, while markets in the East Asian countries failed to do so. We argue that the corporate governance system in Norway protects minority shareholders from expropriation by banks or other insiders, making it easier for firms to obtain financing from equity markets when banks are distressed. Such strong protections are lacking in Japan and other East Asian countries. In support of our argument, we demonstrate that Norwegian companies accessed equity markets more frequently, and obtained greater amounts of financing, than Japanese firms did in the period preceding the crisis. Further, we show in cross-sectional regressions that Norwegian firms issuing equity prior to their bank's distress, and firms with relatively low levels of drawn bank credit, experienced significantly higher announcement-period abnormal returns. Overall, our results suggest that the presence of a well-functioning capital market mitigates the impact of a banking crisis on borrowing firms.

The rest of the paper is organized as follows. Section 2 details the major events surrounding the Norwegian banking crisis. Section 3 discusses the data and introduces the event study methodology used in our paper and Section 4 contains the event study results. Section 5 compares the Norwegian and Japanese financial systems and investigates the cross-sectional variation in borrower abnormal returns. Section 6 concludes.

\section{The Norwegian Banking Crisis}

On March $18^{\text {th }} 1988$, Sunnmørsbanken, a small commercial bank in western Norway, issued an earnings report warning that it had lost all of its equity capital. This event marked the beginning of the 
Norwegian Banking Crisis, a four-year period in which 13 banks representing over $95 \%$ of the total commercial bank assets in Norway, either failed or were seriously impaired. The crisis unfolded along the lines of a "classic financial panic" as described by Kindleberger (1996). A displacement substantial and rapid financial deregulation in the mid-1980s - ignited overtrading in the form of a boom in bank lending. In the midst of the credit expansion, a sudden decline in oil prices precipitated a fall in asset values. Many weak firms went bankrupt, imperiling the banks tied to the failing firms. This led to revulsion in trading in the form of reduced bank lending throughout the economy.

Banking deregulation began in earnest in 1984. Prior to that year, Norwegian authorities limited both the quantity and rates at which Norwegian banks could lend. ${ }^{4}$ In 1984, authorities relaxed reserve requirements, allowed subordinated debt to be counted as bank capital, and opened Norway to competition from both foreign and newly-established Norwegian banks. ${ }^{5}$ Over the next two years, the Norwegian government lifted all interest rate declarations, phased out bond investment requirements, consolidated bank oversight responsibilities under the Banking, Insurance, and Securities Commission (hereafter BISC), and further relaxed restrictions on competition by permitting foreign banks to open branches in Norway. To compete for market share in the newly deregulated environment, banks aggressively expanded lending. Between 1984 and 1986, the volume of lending by financial institutions to firms and households in Norway grew at an annual inflation-adjusted rate of $12 \%$, roughly three times the average growth rate in the years prior to deregulation (see the bottom panel in Figure 1). A large portion of this growth came from new banks, small commercial banks, and savings banks.

The rapid expansion in credit ended in 1987 as bank loan losses began to accumulate. During 1986, the price of North Sea Brent Blend crude oil fell from $\$ 27$ a barrel to $\$ 14.50$ a barrel, precipitating a sharp decline in asset values in the oil-dependent Norwegian economy. Real bank loan growth slowed to $3.6 \%$ in 1988 and $2.8 \%$ in 1989 . Existing loans to cyclically sensitive firms also came into jeopardy. As indicated in Table 1, total bankruptcies in Norway increased from 1,426 establishments in 1986 to 
3,891 in 1988 and 4,536 in 1989. Most of the bankruptcies were small firms concentrated in the real estate, transport, construction, retail store, fishing, hotel, and restaurant industries. ${ }^{6}$ Paralleling these failures, commercial loan losses, measured as a percentage of total bank assets, rose from a level of $0.47 \%$ in 1986 , to $1.57 \%$ in 1988 , and $1.60 \%$ in 1989 (see the bottom panel of Figure 1). The transition from a tightly regulated economy to a more competitive financial marketplace most likely accentuated these losses because of poor decision-making, high risk-taking, and outright fraud in bank lending. ${ }^{7}$ Sunnmørsbanken was the first to announce insolvency. During 1988-89, similar announcements followed from three other small commercial banks and four savings banks. All of these banks were located in northern or western Norway, the regions in which most business failures were occurring.

At the outset of the crisis, the Norwegian government had no formal program for shoring up the capital of troubled banks, nor did it sponsor any form of deposit insurance. Instead, the banking industry managed its own deposit insurance programs. It was these programs - the Commercial Bank Guarantee Fund (CBGF) and Savings Bank Guarantee Fund (SBGF) - which first injected capital into the troubled banks. Under the guidance of the BISC, the CBGF injected NOK 1.3 billion ( $\$ 65$ million) into the impaired banks and arranged for most of them to be merged with healthier banks. One exception was the insolvent Norion, a newly-formed commercial bank that came under investigation by the BISC for fraud in May 1989. The CBGF denied funding to Norion beyond the amount needed to cover liabilities of existing depositors, forcing the government to take over the stricken bank. Within six months, the government had shut the bank down and put its remaining assets under direct administrative control. By Spring 1990, capital injections from the CBGF and consolidations proposed by the BISC appeared to put to rest the outbreak of bank insolvencies. Aftenposten, the largest newspaper in Norway, proclaimed on March 16, 1990 that the "Norwegian banking industry had weathered its worst difficulties" and that "the losses appear now to have flattened out." 
The optimism, however, was premature. Uncertainty created by the Persian Gulf Crisis, weaknesses in global financial markets, and economic downturns in Sweden and Finland diminished the ability for Norwegian banks to borrow abroad. Newspapers began to report that Norway's three largest commercial banks were in trouble. Early in December 1990, Norway's third largest commercial bank, Fokus, announced large losses due primarily to the poor performance of its existing loan portfolio. It had recently acquired two of the original troubled commercial banks. Later in December, Norway's second largest commercial bank, Christiania Bank, announced an unexpected upward adjustment in loan losses, and requested an injection of capital by the CBGF. Christiania Bank had earlier acquired Sunnmørsbanken, the bank to first announce failure. Within two weeks of the Christiania Bank news release, Norway's largest commercial bank, Den norske Bank, also announced an upward revision in its loan loss estimates. All three of the banks publicly recognized that funds previously available through international markets had now dried up or become prohibitively expensive. ${ }^{9}$ The magnitude of the losses at Fokus Bank became apparent in February 1991 when the CBGF announced that a bailout of the bank had depleted nearly all of the remaining capital in the private insurance fund.

Without further aid, the entire banking system was in danger of collapsing. On March 5, 1991, the Norwegian parliament allocated Kr 5 billion to establish the Government Bank Insurance Fund (GBIF). The money in the GBIF was made immediately available for use by the CBGF to finish the bailout of Fokus Bank and to begin injecting capital into Christiania Bank. Shortly after the establishment of the GBIF, Den norske Bank announced that it would also need a large capital infusion to sustain operations. By the Fall of 1991, it became clear that the Kr 5 billion used to start the GBIF would be inadequate for bailing out all three of Norway's largest banks.

After six months of debate on to how to resolve the worsening crisis, the Norwegian parliament increased the size of the GBIF, created a new fund called the Government Bank Investment Fund, and amended existing laws to force each ailing bank to write down its equity capital. This effectively 
allowed the Norwegian government to step in and take control of the three banks. In late 1991, the total size of the government's guarantee funds quadrupled to $\mathrm{Kr} 20$ billion (an amount equal to $3.4 \%$ of GDP) and the Norwegian government completely took over Fokus and Christiania banks and gained control of $55 \%$ of Den norske Bank.

By 1992, the crisis had not only taken its toll on the Norwegian banking system, but had also spread to other Nordic countries. In Norway, only eight domestic commercial banks remained in operation and $85 \%$ of the country's commercial bank assets were under government control. Most large savings banks, mortgage companies, and finance companies had also experienced record losses during the period, and in 1993, Norway's largest insurance provider was forced into government stewardship. Sweden and Finland experienced similar patterns of distress as bank loan losses in 1992 climbed to over $5 \%$ of total bank assets and authorities in each country took unprecedented steps to rescue ailing banks (see Drees and Pazarbasioglu (1995)).

Three points should be made about the Norwegian banking crisis. First, responses to the unfolding crisis were unclear ex-ante, making it unlikely that investors could have predicted the ex-post outcomes. No bank had failed in Norway since 1923 and the Norwegian government had taken a "hands-off" approach to insuring depositors against failure. Moreover, bank representatives made it clear at the beginning of the crisis that state intervention was unnecessary, if not undesirable. For instance, Tor Kobberstad, head of the Norwegian Bankers Association (Bankforeningen), stated in October 1989,

A bank that is poorly managed should not be allowed to continue on forever, it sets bad precedent for the industry. If we're going to maintain a private banking system, we should do it through resources from banks within the system. One should be extremely careful about trying to solve problems through state assistance. ${ }^{10}$ 
Second, government intervention led to disruptive changes at the distressed banks. The first time the government stepped in, it liquidated Norion Bank. In exchange for an injection of capital, the GBIF required ailing banks to write down their capital, replace management, cut costs, and scale back their branch networks. ${ }^{11}$ Subsequent control of the three largest banks indeed led to dismissal of the boards of directors and top management at both Fokus and Christiania Bank. ${ }^{12}$ Third, the impact of the crisis on the banking industry has been long-lasting. As of September 2000, the Norwegian Government

continued to hold large or controlling stakes in Norway's two largest commercial banks. ${ }^{13}$ Moreover, the stock market value of Norwegian banks did not recover to their pre-crisis levels until the summer of 1997.

\section{Data and Event Study Methodology}

Given the history of the Norwegian banking crisis, we now turn to the data and methodology used to analyze the impact of bank distress announcements on the stock prices of firms maintaining relationships with distressed banks

\subsection{Relationship, announcement, and stock price data}

We start with a time-series of firm-bank relationships compiled by Ongena and Smith (2000). For their study, Ongena and Smith (2000) collect annual information on the identity of bank relationships maintained by non-financial firms listed on the OSE between 1979 and $1995 .{ }^{14}$ The sample covers, on average, $95 \%$ of all non-bank firms listed on the OSE during that period. Although these firms represented less than $0.10 \%$ of the total number of incorporated companies in Norway, their book equity value in 1995 accounted for $21 \%$ of total corporation equity, and their market value equaled $45 \%$ of GDP (Bøhren and Ødegaard (2000)). The sample firms maintained relationships with a total of 55 different banks, including 24 Norwegian commercial banks, 15 international commercial banks, and 17 
Norwegian savings banks. During an average year, $74 \%$ of the firms maintained a relationship with only one bank and only $2 \%$ maintained four or more bank relationships.

Table 1 provides an annual overview of the turnover in bank relationships, along with the total number of firms listed on the OSE, the total number of bankruptcies across all firms in Norway, and the number of firms delisting from the OSE each year, from 1980 to 1995. During this period the OSE listed an average of 130 firms. The number of firms going public increased markedly during the early 1980s, a period in which substantial deregulation and modernization occurred in the stock market, including the lifting of prohibitions on foreign purchases of equity in 1984 and in the introduction of U.S.-styled insider trading regulations in 1985. With the exception of 1990, delistings of OSE firms remained relatively constant throughout the crisis period even as total bankruptcies in the country rose. In fact, the net number of firms listing on the OSE grew each year after 1990. The average number of firms starting new bank relationships and ending existing relationships tripled during the years 19861988, compared to the average turnover in prior years. ${ }^{15}$ Beginning in 1989 , firms scaled back on the number of bank relationships they terminated, but continued to add new relationships at a rate triple to that prior to deregulation.

We match the Ongena and Smith (2000) relationship data with a set of announcements of distress made by banks involved in the Norwegian banking crisis. We start with a list of all crisisrelated bank announcements that appeared on the OSE wire service or in the annual reports of governmental and quasi-governmental agencies, compiled by Kaen and Michalsen (1997). To this list we add announcements appearing in major Norwegian newspapers during the crisis period. We then define an event to be the date that the first material announcement of distress by a bank appears in one of our news sources. Such an announcement commonly includes a statement about severe loan losses, inadequate reserves, or large capital losses. We obtain thirteen announcements covering a period between March 1988 and January 1991. To these we add the announcement on June 17, 1991 that both 
Den norske Bank and Christiania Bank had requested an injection of capital via government-purchased preferred equity. This request was the first indication that the magnitude of losses at Norway's two largest banks outstripped the existing capital of the government guarantee fund, and was the effective start of a series of highly publicized parliamentary and newspaper debates discussing the prospect for rescuing the banking system. In matching the bank announcements with firm-bank relationships, we require the distressed bank to be associated with at least one firm from the Ongena and Smith (2000) database. Because some of the distressed banks did not service publicly-traded firms, our criterion leaves us with five banks and six distress events. In 1990, these five banks maintained relationships with 108 OSE listed firms, representing $96 \%$ of the firms in our sample at that time.

Table 2 contains the event dates and a short description of each distress announcement. It also reports the number of exchange-listed firms maintaining a relationship with each distressed bank, as well as the number of exchange-listed firms maintaining relationships with non-distressed banks during the three years surrounding each distress date. Henceforth, we refer to firms that maintain a relationship with a distressed bank as "related firms" and those that maintain relationships with non-distressed banks as "unrelated firms". We obtain a total of 217 related firm observations and 447 unrelated firm observations across the six events.

For the analysis, we also require ownership, financial and stock price data. For these data we rely on Kierulf's Handbook and data supplied by Oslo Børs Informasjon, an information subsidiary of the OSE. Our analysis requires that we have a complete stock price history for the firms in the 291 trading days surrounding the distress event and complete accounting information in the year prior to the event. ${ }^{16}$ With these screens in place, we are left with 169 related firm observations and 267 unrelated firm observations.

We report results using both a value-weighted index of all OSE stocks and a "world" market index as measures of the benchmark market return. To construct the world market index, we gather 
from DataStream the value-weighted returns from the US, Japanese, UK, and German stock market indexes. Each country receives a weight in the world index proportional to its US dollar market capitalization as of July $1^{\text {st }}, 1987$. Judging abnormal returns relative to a world market index sidesteps biases in the OSE created by the correlation between the Norwegian economy and the banking crisis. For example, estimates of event-day abnormal returns will be biased upward if the Norwegian stock market falls on news correlated with a bank's announcement of distress.

\subsection{Event study methodology}

To obtain estimates of abnormal returns, we run market model regressions of the realized daily stock return for event portfolio $j, r_{j t}$, on a measure of the realized daily return of the market index, $r_{m t}$, and a set of $2 \tau+1$ daily event dummies, $\delta_{j k t}, k=-\tau,-\tau+1, \ldots, 0, \ldots, \tau-1, \tau$, which take the value of one for days inside the event window $(t=k)$, and zero outside the window,

$$
\text { (1) } \quad r_{j t}=\alpha_{j}+\beta_{j} r_{m t}+\sum_{k=-\tau}^{\tau} \gamma_{j k} \delta_{j k t}+\varepsilon_{j t}
$$

The coefficients $\gamma_{j k}$ measure the daily abnormal returns inside the event window. For the results reported in the tables, we start the estimation 150 days prior to the start of the event window, include up to 40 days inside the window, and end the estimation 100 days after the event window. Because nontrading of stocks is a common problem on the OSE, we check all our results by adding three lead and lagged values of the market index to to correct for non-synchronous trading. Sums of the daily abnormal return estimates $\hat{\gamma}_{\mathrm{jk}}$ over various windows yield cumulative abnormal return (CAR) estimates, which can be tested for significance using a Wald test. 


\section{Impact of Bank Distress Announcements}

This section presents the event study results by first documenting the impact of distress announcements on the banks themselves. By first studying the stock price reaction of the troubled banks to the distress announcements, we can jointly gauge the informativeness of the chosen event dates and the economic magnitude of the announcements.

Table 3 reports individual and average bank CARs using both the OSE index and the world market index over various windows surrounding announcements of distress. Because the two benchmarks generally produce similar CAR estimates, we focus in the text on estimates measured relative to the world market index. Stock price data for Sparebanken Nord-Norge are not available before 1994, so this bank is excluded from Table 3.

To summarize the CAR estimates across events, we report averages using two different methods. The first takes a simple average of the CARs, assumes that the estimates are independent across events, and uses a t-test to judge significance. ${ }^{17}$ The second method uses a seemingly unrelated regression (SUR) framework that jointly incorporates all of announcements assuming that the price impact across banks is equal. The latter method averages the individual bank estimates using weights proportional to the standard deviation of the event-specific error terms (see Thompson (1985)).

From a distressed bank's perspective, the events had a substantial impact on stock price. Across the events, the post event CARs are negative, large, and statistically significant, suggesting that our event date choices were surprising to investors. For instance, the stock prices of Den norske Bank and Christiania Bank were increasing over the 10 days prior to their bailout request on June 17, 1991, but fell more than $9 \%$ immediately after the announcement was made. On average, the set of distressed banks earned zero abnormal returns leading up to the distress event and experienced an announcementday decline of roughly $10 \%$ that persisted beyond the 10 day post-announcement window. These 
averages are not only statistically significant, but economically meaningful. For example, on an aggregate basis, the $(-1,+1)$ and $(-3,+3)$ event windows capture $38 \%$ and $58 \%$, respectively, of the total price fall in Norwegian bank stocks over the period 1988-1991.

We now turn to examining the abnormal returns of the related firms around bank distress announcements. Table 4 reports event-specific CAR estimates based upon equally weighted portfolios of related firms, grouped by event, and average CARs across all events. The signs and magnitude of the related firm portfolio CARs tend to be more mixed across events than the bank CARs. Over the $(-1,+1)$ event window, borrowers from Sparebanken Nord-Norge fell by $26 \%$, while firms related to Sunnmørsbanken and Fokus Bank declined by $6 \%$. However, over the longer $(-3,+3)$ and $(0,+10)$ windows, "reversals" can be observed in returns for firms related to Sunmørsbanken and Sparebanken Nord-Norge. That is, their cumulative abnormal returns are higher over these longer event windows than for the 3-day event window. This volatility is not surprising given that only 5 firms are associated with these two banks, and customers of these smaller banks tend to smaller and risky themselves. Firms related to Christiania Bank and Den norske Bank suffered less upon their banks' first announcement of distress. These borrowers experienced abnormal price drops that averaged $-2.5 \%$ over the short $(-1,+1)$ window, zero over the $(-3,+3)$ window, and slightly positive for the $(0,+10)$ period. Moreover, these same firms experienced a relatively mild 3-day decline of $-0.3 \%$ - while their banks' experienced their largest stock price decline - upon the announcement that bank losses exceeded the existing capital of the government guarantee fund. Over longer windows, related firm stock prices once again tended to bounce back.

To get a consistent view of the aggregate impact of these distress announcements on the related firms, the bottom of Table 4 reports the average CARs across all firms. To create the average, we first estimate the market model regression on a firm-by-firm basis and calculate the mean CAR across all 169 firm estimates. Then, in order to control for the cross-sectional dependence in CAR estimates, we 
generate standard errors from bootstrapped distributions that preserve the cross-sectional dependence in the market model error terms $\varepsilon_{i t}$ for firms with event dates that overlap in time (the Appendix contains a detailed description of the bootstrap procedure).

Using the boot-strapped errors, the average 3-day CAR estimate is a statistically significant $1.4 \%{ }^{18}$ Assuming that this estimate represented a permanent change in the average value of an OSE firm would imply a total wealth loss of NOK 3.8 billion (measured in 1990 Norwegian Kroner) on the OSE. Such a loss amounts to about 1/5 of the bailout paid by the Norwegian government to the depositors at Norway's two largest banks, and about 1/20 of the total estimated losses experienced by banks between 1988 and 1992. Thus, the negative 3-day abnormal return, if permanent, would be economically small. But because the firm prices tend to reverse themselves, the negative stock price reaction is temporary. Over the 7 - and 10-day event windows, the average CARs are $+1.7 \%$ and $+1.4 \%$ and statistically insignificant.

At the bottom of Table 4, we also report an estimate that judges the performance of related firms relative to unrelated firms over the event period. Specifically, we construct a firm-weighted "difference" portfolio that assumes that investors can form a zero cost portfolio before the event date that is long in related firms and short in unrelated firms. To create the portfolio, each firm receives a weight that is proportional to the total number of firms in the sample that year. The difference portfolio CAR estimates suggest that the stock prices of related firms fall by more than unrelated firms on event dates, but that the difference is not statistically significant.

\section{Further Exploration}

In the last section, we showed that Norwegian banks experienced permanent, economically meaningful, and statistically significant negative abnormal returns on the chosen distress dates, yet firms related to the banks experienced only a small and temporary decline in their stock price. These findings stand in 
contrast to recent empirical evidence from other countries experiencing financial crises. In this section, we address this disparity in results by first comparing the financial systems of Norway and Japan, and then by exploring the cross-sectional variation in Norwegian firm CARs as a function of a set of explanatory variables related to the financial, governance and relationship characteristics of the firm.

Although we could make similar comparisons between Norway and other East Asian economies that experienced a financial crisis, we focus the comparison on Japan for several reasons. First, Japan is developmentally close to Norway, with a per-capita GDP nearly equal to that in Norway. Japan's banking crisis began at about the same time as Norway's and the crises shared many similarities. Second, a good deal of empirical evidence exists about the Japanese financial system and its recent crisis. Third, though both financial systems are "bank-dominated" in the sense that banks supply nearly all commercial credit, Japan's system of corporate governance differs significantly from Norway's. We argue that these differences have had important consequences for how each country has responded to its financial crisis.

\subsection{A comparison of the Norwegian and Japanese financials systems}

Much of what happened in Japan during its banking crisis mirrors the experience in Norway. ${ }^{19}$ Financial deregulation during the 1980s fueled expansive bank lending. Growth in credit coincided with a large run-up in financial and real estate prices during what became known as the "Japanese bubble" years. Asset prices collapsed during 1990-91, weakening the ability for borrowers to meet interest payments and lowering the value of asset-backed loans. Lending contracted as banks began to suffer. The first financial institutions to suffer large losses, bank-owned mortgage companies called jûsen, began to go bankrupt in 1991. Announcements of insolvency soon followed from small commercial banks, and eventually, larger banks. At first, Japanese authorities relied on the banking industry to prop up failing institutions through mergers and direct financial assistance from healthier banks. But as the crisis 
worsened, the government stepped in to save troubled banks by injecting capital into the banking system and ultimately taking control of two of Japan's largest banks.

Yet while authorities in Norway managed to stem financial losses by turning the Norwegian crisis around in four years, the Japanese banking system continues to deteriorate. As of March 2000, realized loan losses at Japanese banks since 1992 have amounted to 14.8\% of GDP, and banks estimate the level of remaining bad loans to be as high as $18.3 \%$ of GDP. ${ }^{20}$ Comparatively, total loan losses at Norwegian banks during the years 1988-92 amounted to 8.4\% of GDP and dropped back to pre-crisis levels by the end of $1992 .^{21}$ Moreover, Japan has already committed 70 trillion yen (about $16 \%$ of GDP) in public funds to the rescue of its ailing banks and many analysts suspect that future bank bailouts are imminent. $^{22}$ The continued deterioration of the Japanese banking sector has coincided with relatively slow economic growth in the country. For example, between 1990 and 1999, nominal Japanese GDP grew at an average annual rate of $1.85 \%$. This growth rate compares with $5.25 \%$ in Norway over the same period (IMF (1999)).

What has caused the disparity in recovery between the two systems? One of the primary differences between the Norwegian and Japanese financial systems is the degree of control banks have over the decision-making of their borrowers. Banks are not just important providers of commercial credit in Japan, they also exert substantial control over the voting rights of the firm's owners. ${ }^{23}$ Prowse (1992) estimates that commercial banks hold an average of $20 \%$ of the voting equity in Japanese companies and Claessens et al. (2000) find that banks control 39\% of all publicly-traded Japanese corporations when the largest controlling block is at least $10 \%$ of voting shares. ${ }^{24}$ Japanese bankers are also omnipresent on the boards of directors of non-financial firms. For instance, Morck and Nakamura (1999) report that 171 bank managers were appointed to board positions of 383 large Japanese firms over the period 1981-87 period, implying that an average of $45 \%$ of the firms appointed a banker on their board during that time period. 
While banks exert substantial equity-type control over Japanese corporations, they own a relatively small proportion of equity cash flow rights. ${ }^{25}$ For instance, Claessens et al. (2000) estimate that owners of Japanese companies controlled by financial institutions hold 2 shares of voting rights for every one share of cash flow rights, a ratio that far exceeds that of the other nine East Asian countries in their study. This separation tends to drive a wedge between ownership and control and distort incentives away from maximizing shareholder wealth. Japanese banks have more incentive to maximize the value of their debt positions where they receive the bulk of their cash flows through loan repayments (Morck and Nakamura (1999)). Bank control over management also increases the opportunity for Japanese bankers to extract monopoly rents from their borrowers by threatening to holdup financing while preventing the borrowers from seeking financing elsewhere (Weinstein and Yafeh (1998)). Distortions created by the separation of ownership and control by banks could become particularly onerous when banks are financially distressed. For instance, bank managers could encourage too much risk-taking when failure guarantees a bailout (Keeley (1990)), particularly if they believe their job will when the government forces unsuccessful banks out of business (Gorton and Rosen (1995) and Dinç (2000)). Bank managers of unhealthy banks will also be more inclined to refinance poorly performing loans to avoid having to increase reserves or write off bad loans. Indeed, some experts point to the "evergreening" of bad loans in Japan as the main impediment to economic recovery. ${ }^{26}$

In contrast to Japan, banks in Norway play virtually no role in the control of firms beyond what is contractually accorded to them as lender. Bøhren and Ødegaard (2000) report that Norwegian banks own or control an average of $1 \%$ of the equity in OSE-listed firms. ${ }^{27}$ Banks in Norway also rarely place representatives on the boards of non-bank companies. Over the period 1985-1992, 16 bankers were appointed to boards across 209 exchange-listed companies, implying that only $8 \%$ of the firms appointed a banker to their board during this time period. 
Meanwhile, minority equity shareholders in Norway enjoy relatively strong protection against encroachment by controlling parties not interested in improving shareholder wealth.. According to La Porta, Lopez-de-Silanes, Shleifer and Vishny (1998), Norway's legal system ranks among the top for protection of minority equity-holders, coming in highest of all Scandinavian countries and equaling the average of the investor-friendly, common law countries. Japan scores equally high on the La Porta et al. (1998) index, but Japan's score masks a governance structure that in practice works against minority shareholders. Cooke and Kikuya (1992) note that Japanese companies rely on intercorporate shareholding, a culture of voting by "following the leader" (i.e., the controlling shareholder), and even corporate extortionists called sokaiya to "quiet" minority shareholder opinions at shareholder meetings. By contrast, Norwegian securities law prohibits corporate charters from limiting minority shareholder rights, and encourages shareholders to use legal counsel and court action to assure that their opinions are heard at shareholder meetings (Bøhren and Ødegaard (2000)).

In addition, accounting and disclosure standards in Norway are more transparent than in Japan, heightening the ability for outside shareholders to protect their interests. According to La Porta et al. (1998), Norway's accounting standards rank in the top $20 \%$ of the 41 countries for which they have rankings, while Japan's are ranked at the median. Norwegian law requires company insiders and large shareholders to disclose all holdings and trades, forbids trading on private information, and prohibits company insiders from trading around earnings announcements (Eckbo and Smith (1998)). By contrast, Japanese regulators currently do not require reporting of trades by company insiders, and did not institute laws to prohibit insider trading until 1988 (Bhattacharya and Daouk (2000)). Moreover, Japanese authorities have only recently recognized the importance of transparency in disclosure standards as part of "Big Bang” reforms proposed in 1996 (Royama (2000)).

To get a sense for the protection of minority shareholders in each country, consider the degree of foreign ownership in each country. Foreign investors are invariably “outsiders" to a given country's 
stock market and can serve as an indicator for how much protection outside shareholders get inside a country's borders. In 1990, at about the midpoint of the Norwegian financial crisis, ownership by foreigners accounted for $29 \%$ of the market capitalization on the OSE. In that same year, near the peak of the Japanese stock market, foreigners owned only $4 \%$ of the value of the Tokyo Stock Exchange. ${ }^{28}$

\subsection{Equity issuance behavior in Norway and Japan}

We have argued that banks in Japan maintain control rights over borrowing firms that greatly exceeds their cash flow rights, and that this imbalance creates incentives for banks to act in ways counter to minority shareholder wealth maximization, especially when banks are distressed. We have also argued that Norwegian banks do not exert control rights over borrowing firms beyond that as a lender and that Norwegian shareholders are protected from expropriation by strong legal and institutional standards.

One way to check our assertions is to observe the ability of firms in each country to exploit sources of financing other than their banks. Exchange-listed firms have an obvious alternative financing source to draw on: the equity market. Firms that are not dependent on banks as their sole source of financing should be able to draw on equity markets in times where their banks are distressed. This freedom has two benefits. First, it mitigates the possibility that the bank can hold up financing to firms with valuable investment opportunities. Second, because the equity issuance process requires firms to go through a screening process with investment banks, it provides a mechanism for credibly disseminating information to investors about firm value.

Table 5 compares the recent equity issuance behavior of Japanese and Norwegian firms. It reports the total number of equity-type issues, the number of issues as a proportion of listed firms, and issue amounts as a fraction of market capitalization made by non-financial firms in both countries over the period 1985 to 1996. The sources for these are described in the Appendix. We include convertible bond issues for Japan because they are a popular method for indirectly issuing equity in that country (Kang and Stulz (1996)). Convertible bond issues in Norway are relatively rare. Compared to Norway, 
equity-type offerings in Japan are infrequent and relatively small. As a proportion of the total number of listed firms, Japanese equity issues peaked in 1989 at $27 \%$ and fell off quickly afterwards. As late as 1996, only $10 \%$ of Japanese firms were issuing equity. By comparison, an average of $33 \%$ of Norwegian firms issued equity each year (6\% higher than Japan's peak year), equity issuances barely fell off during the Norwegian banking crisis, and nearly half of all OSE firms issued equity each year by 1996. The size of equity offerings in Norway is also larger than that in Japan. Norwegian firms raised an average of $4 \%$ of total stock market each year while Japanese firms raised $1 \%$. Because the frequency of issues in Norway is approximately double that in Japan, the average issue size in Norway is roughly twice that in Japan, measured in proportion to stock market value. Overall, Norwegian firms appear to have had a great deal more flexibility in the issuance of equity than Japanese firms did over this period.

\subsection{Cross-sectional Regressions}

To gain a better understanding of the patterns underlying the abnormal returns documented in Table 4, we now move to cross-sectional regressions of related firm CARs on a set of variables related to the financial, governance, and bank relationship characteristics. The variables are selected to measure a Norwegian firm's dependence on one bank's financing versus its ability to obtain financing from other sources. We hypothesize that firms dependent on bank financing should experience larger negative stock price shocks on the day their banks announce distress than firms that have other means for financing new projects. Unless otherwise specified, we measure all variables at the end of the year prior

to the distress announcement. We provide a description of the variables below and summary statistics in Table 6.

Firm-specific information asymmetries could prevent some firms from accessing funds from outside sources. We include two indicators of potential information problems at the firm level. The first variable, LN SALES, measures the size of the firm in terms of the logarithm of sales, measured in 
1979 Kroner, and the second variable, AGE, is the number of years the firm has been in operation since its founding date. Larger firms are likely to be better known among analysts, news services, and traders, while older firms benefit from an established reputation.

We include the variable DEBT, defined to be total book value of firm debt divided by the sum of book value of debt and market value of equity. Because firms in Norway rely heavily on banks for debt financing in Norway, DEBT serves as a proxy for the amount of bank debt a firm carries in its capital structure.

We construct two variables to measure a firm's ability to finance investments through available liquid sources of financing. CASH FLOW, defined to be net income plus depreciation divided by the book value of assets, provides an estimate of the level of cash available to the firm at the time of the distress announcement. DRAWN CREDIT is the amount of credit drawn on the firm's loan commitments divided by book value of assets. Firms that have low levels of drawn credit should be less liquidity-constrained and have more short-run financial flexibility than firms with high levels of drawn credit.

Because banks can gain valuable private information from about a customer over the course of a relationship, firms with a strong relationship to a distressed bank may find it difficult to obtain financing elsewhere. We include three variables related directly to the strength of a firm's relationship with a distressed bank. TERMINATION PROPENSITY measures the ex-ante likelihood that a firm will terminate its bank relationship, conditional on the duration of the relationship in the year prior to the distress announcement. The variable is constructed by fitting a conditional hazard rate model to the relationship data provided by Ongena and Smith (2000) and is included as a proxy for the ease with which a firm can switch relationships. The termination propensity model allows relationship duration to vary as a function of firm size, age, leverage, profitability, and the number of relationships maintained by the firm. Ongena and Smith (2000) show that these variables are strong predictors of the termination 
behavior of Norwegian firms. We include the dummy variables HEALTHY BANK, set equal to one when a firm also maintains a relationship with a bank not in distress, and INTERNATIONAL BANK, set equal one when a firm maintains a relationship with a non-Norwegian bank. Both dummy variables indicate potential sources of substitute bank funding at the time of the crisis. Firms maintaining relationships with healthy Norwegian banks or foreign banks should be less susceptible to the impairment of their distressed bank.

We incorporate two variables motivated by the comparison with Japan. BANKER ON BOARD is a dummy variable that takes the value of one when a bank officer from the distressed bank sits on the board of directors of the firm. Though rare in Norway (only $2 \%$ of the sample firms have a distressed banker on their board), firms with bankers on their boards might experience conflicts of interest similar to those of Japanese firms. EQUITY ISSUE is the total amount of public and private equity raised by the firm in the two years prior to the distress event, divided by firm book value of asset. Based on our arguments above, firms that recently issued equity should be less dependent on their distressed bank than firms that have not recently issued equity.

Finally, we include two variables from the distress announcement to control for possible biases in the CARs related to investor anticipation of the event. BANKCAR, defined to be the 3-day CAR estimate for the distressed bank, acts as a measure of the level of surprise in the distressed announcement, weighted by the magnitude of the announced losses. Including BANKCAR also controls for variation in the nature of the distress announcement. For example, an official announcement of loan loss adjustments could be perceived differently than unconfirmed rumors of financial problems. The second variable, CRISIS LENGTH, is the logarithm of the number of days between the date of a particular distress announcement and the date of the first distress announcement (March 18, 1988). As the bank crisis unfolds, investor expectations about the entire banking sector could change, altering the informational content of distress announcements for individual banks. If the seriousness of the crisis 
becomes more apparent as time passes, then new announcements should become less informative over time.

\subsection{Regression results}

Table 7 contains the results from regressing $(-1,+1)$ and $(-3,+3)$ related firm CARs (stated in percent terms) on various combinations of the explanatory variables. We include both sets of CARs to extract patterns that persist outside of the three days surrounding the event. The p-values under the coefficient estimates (in parentheses) are based on the same bootstrapping procedure used in Table 4 that preserves the cross-sectional error structure of firms associated with the same event.

The first thing to note from the results in Table 7 is that most of the coefficient estimates are statistically insignificant and that the variables together explain very little of the variation in the related firm CARs. The highest adjusted R-squared using the $(-1,+1)$ CAR is $1.4 \%$, while the highest for the ($3,+3)$ CAR is $4.4 \%$. Nevertheless, a certain number of interesting patterns emerge. First, EQUITY ISSUE has a positive and statistically significant coefficient estimate in four of the six specifications that remains robust across both dependent variable specifications. The estimates suggest that every dollar of new equity issued on 100 dollars of assets in the two years prior to the distress announcement leads to an increase of 90-125 basis points in the $(-3,+3)$ CAR. Second, firms with high levels of drawn credit perform relatively poorly over the $(-3,+3)$ event window. The estimate on DRAWN CREDIT implies that each additional dollar of drawn credit per 100 dollars of assets decreases the 7-day CAR by

over 500 basis points. If the level of drawn credit accurately depicts the degree of financial flexibility a firm has to meet short-run investment needs, then our evidence suggests that firms with less financial flexibility are hurt more when their banks announce distress.

Finally, the signs on AGE, HEALTHY BANK, and INTERNATIONAL BANK are often statistically significant, but counter-intuitive. AGE is negative and statistically significant at a $10 \%$ level or better in three of the six specifications, suggesting that older firms are hurt more by bank 
distress than younger firms. Although this relation tends conflict with standard information-based stories of bank dependency, this result is consistent with Ongena and Smith (2000), who find that young firms switch out of bank relationships more frequently than older firms, making small firms less dependent on any one bank relationship. The negative sign on INTERNATIONAL BANK in the regressions (1a) - (3a) and on HEALTHY BANK in regressions (1b)-(3b) suggest that firms with alternative bank sources of funding perform more poorly than those firms without other bank funding. If healthy banks infer that troubled banks are distressed because their related firms have made poor investment choices, then the distress announcement could make healthy banks more reluctant to lend to the related firms in the future.

Overall, our cross-sectional results provide support for the argument that firms that cannot draw on liquid sources of funding, or that are unable to access capital markets prior to their bank's distress are more negatively impacted by their bank's announcement of distress.

\section{Conclusion}

The Norwegian banking system was in deep financial trouble between 1988 and 1991. Loan losses exhausted capital at many banks, private deposit insurance funds went broke, the banking sector nearly collapsed, and Norway's largest banks were ultimately nationalized. Nevertheless, the average firm maintaining a bank relationship with a distressed bank faced only small and temporary downward revisions to its stock price on the announcement of their banks' distress. In fact, stock prices of publiclylisted companies grew over the event period, outstripping the average returns on other exchanges around the world. Our results suggest that bank distress caused no significant interruptions to the financing and investment abilities of exchange-listed Norwegian firms despite the fact that these firms were heavily reliant on bank debt as a source of bank financing. 
We argue that because the Norwegian financial system leans towards protections for minority shareholder rights and transparent accounting and disclosure, banks are unable to consistently establish strong control rights over firms in Norway like they can in Japan. Instead, investors in Norway work through a well-functioning equity market to control firms in a way that maximizes shareholder value. As direct evidence for this argument, we show that Norwegian firms issued equity more often, and in greater amounts, than Japanese firms - even when the Japanese stock market was at its peak. Crosssectional regressions strengthen the argument by demonstrating that Norwegian firms with access to liquid funds or that issued equity prior to the banking crisis experienced relatively high abnormal returns. 


\section{Appendix: Bootstrapping Procedure}

To obtain a distribution for the average CAR across all events that accounts for the cross-sectional (and cross-event) correlation in firm error terms, we firat regress the realized daily return of the stock for each firm $i, r_{i t}$, on the realized daily return on the world market index in period $t, r_{m t}$, and 41 event dummies, $\delta_{j k t}$. We also include three leads and lags of the market index to control for nonsynchronous trading,

(A.1) $\quad r_{i t}=\alpha_{i}+\sum_{n=-3}^{3} \beta_{i n} r_{m, t+n}+\sum_{k=-20}^{20} \gamma_{i k} \delta_{j k t}+\varepsilon_{i t}, t=-170,-169, \ldots, 120 ; i=1,2, \ldots, I$.

$\varepsilon_{i t}$ is an error term. Let $I_{j}$ represent the number of firms involved with event $j$ and $I=\sum_{j=1}^{6} I_{j}$. Denote

the estimated coefficients as $\hat{\alpha}_{i}, \hat{\beta}_{i n}$, and $\hat{\gamma}_{i k}$ and note that the CAR is the sum of the daily abnormal return estimates over the event window.

We draw our bootstrapped data by first drawing with replacement 291 integer index values from a uniform distribution defined over the interval $-170,-169, \ldots, 120$. For each draw, we store the results in a vector. These independent draws determine the dates of the original errors that will be used to sequentially fill in the new time-series of 291 daily observations. Based on this vector, we will then draw the OLS residuals corresponding to the index values for each of the $I_{j}$ firms involved in the event. If the next chronological event is non-overlapping, we repeat this process of drawing 291 index values and matching firm OLS errors with the index values. If part of the next chronological event overlaps with the first, we use the index values from the first event plus or minus the distance in event time between the two events for the overlapping portion. We repeat this process for all six events. By drawing the bootstrapped data in this manner, we preserve both the within-event and cross-event error 
dependencies in the data. Note, however, that we otherwise assume that the data is independently distributed through time.

For one completed draw of data, we then calculate for each firm the bootstrapped daily return of the stock, $\hat{r}_{i t}^{1}$,

(A.2) $\hat{r}_{i t}^{1}=\hat{\alpha}_{i}+\sum_{n=-3}^{3} \hat{\beta}_{i n} r_{m, t+n}+\sum_{k=-20}^{20} \hat{\gamma}_{i k} \delta_{j k t}+\hat{\varepsilon}_{i \tau}^{1}$, where $t=-170,-169, \ldots, 120 ; \tau=\tau_{-170}^{j}, \tau_{-169}^{j}, \ldots, \tau_{120}^{j} ; i=1,2, \ldots, I$,

$\hat{\varepsilon}_{i t}^{1}$ is the $t$-th OLS residual order according to the index values drawn above and the superscript 1 refers to the first draw of data.

Once the new set of returns has been created, we can run regressions similar to (1) and (A.1) to estimate daily firm-level abnormal returns, firm-level CARs, and average CARs across firms. We repeat this procedure 150 times to generate a distribution of the estimates. From this distribution we compute the empirical p-values reported in Tables 4 and 7. A similar procedure is then also used to bootstrap distributions for the estimated coefficients in the cross-sectional regressions. 


\section{Appendix: Equity Offering Data}

The seasoned Norwegian issues are provided by Øyvind Norli and consist of all public, rights, and private equity offerings made by non-financial firms listed on the Oslo Stock Exchange (OSE), based upon OSE Annual Reports (see Norli (1998)). We add initial public offerings, taken from Helland and Samuelson (1999), to the category of public equity offerings. To calculate the Norwegian ratio of total equity raised to OSE market capitalization, we use data from the OSE Annual Statistics. The Japanese issues consist of all initial and seasoned public, rights, and private equity and all convertible bond issues (both and foreign) made by non-financial firms listed on Japanese stock exchanges. The numbers come from the Tokyo Stock Exchange (TSE)'s Annual Securities Statistics. For the Japanese ratio of total equity raised to market capitalization we use the TSE Fact Book, which limits the sample to TSE firms only. 


\section{References}

Allen, F., Gale, D., 2000. Comparing Financial Systems. MIT Press, Cambridge MA.

Bae, K.H., Kang, J.K., Lim, C.W., 2000. The Costs of a Bank-Centered Financial System: Evidence from the Effect of Banking Shocks on Firm Value in Korea. Mimeo. Hong Kong University of Science and Technology.

Bayoumi, T., 1999. The Morning After: Explaining the Slowdown in Japanese Growth in the 1990s. Working Paper. National Bureau of Economic Research.

Bernanke, B.S., 1983. Nonmonetary Effects of the Financial Crisis in the Propagation of the Great Depression. American Economic Review 73, 257-276.

Bhattacharya, U., Daouk, H., 2000. The World Price of Insider Trading. Mimeo. Indiana University.

Black, F., 1975. Bank Funds Management in an Efficient Market. Journal of Financial Economics 2, 323-339.

Bøhren, Ø., Norli, Ø., 1997. Determinants of Intercorporate Shareholdings. European Finance Review 1, 265-287.

Bøhren, Ø., Ødegaard, B.A., 2000. The Ownership Structure of Norwegian Firms: Characteristics of an Outlier. Mimeo. Norwegian School of Management BI.

Claessens, S., Djankov, S.D., Lang, L.H.P., 2000. The Separation of Ownership and Control in East Asian Corporations. Journal of Financial Economics 58, 81-112.

Cooke, T.E., Kikuya, M., 1992. Financial Reporting in Japan. Blackwell Publishers, Cambridge MA.

Dinç, I., 2000. How Were Japanese Bank Managers Protected from Shareholder Discipline? The Shareholding Structure of Japanese banks and Their Real Estate Lending in the 1980s. Working Paper. University of Michigan Business School.

Djankov, S.D., Jindra, J., Klapper, L., 2000. Corporate Valuation and the Resolution of Bank Insolvency in East Asia. Mimeo. World Bank.

Drees, B., Pazarbasioglu, C., 1995. The Nordic Banking Crises: Pitfalls in Financial Liberalization. Working Paper. International Monetary Fund.

Eckbo, B., Smith, D.C., 1998. The Conditional Performance of Insider Trades. The Journal of Finance 53, 467-498.

Fama, E.F., 1980. Banking in the Theory of Finance. Journal of Monetary Economics 6, 39-57.

Fukao, M., 1998. Japanese Financial Instability and Weaknesses in the Corporate Governance Structure. Discussion Paper. Keio University.

Gibson, M.S., 1995. Can Bank Health Affect Investment? Evidence from Japan. Journal of Business 68, 281-308.

Gibson, M.S., 1997. More Evidence on the Link between Bank Health and Investment in Japan. Journal of Japanese International Economics 11, 29-49.

Gorton, G., Rosen, R., 1995. Corporate Control, Portfolio Choice and the Decline of Banking. Journal of Finance 50, 1377-1397.

Greenspan, A., 1999. Lessons from the Global Crisis, Remarks Made before the World Bank Group and the International Monetary Fund on September 27, 1999.

http://www.federalreserve.gov/boarddocs/speeches/1999/.

Helland, E., Samuelson, N., 1999. Cyclical Patterns of Stock Market Introductions and Initial Public Offerings on the Oslo Stock Exchange 1881-1998. Master of Science Thesis. Norwegian School of Management BI.

Hoshi, T., Kashyap, A., 2000. The Japanese Banking Crisis: Where Did It Come From and How Will It End? In: Bernanke, B. and Rogoff, K. (Ed.), NBER Macroeconomics Annual. National Bureau of Economic Research, Cambridge MA, Forthcoming.

Hoshi, T., Patrick, H., 2000. Crisis and Change in the Japanese Financial System. Kluwer Academic, Boston MA. 
IMF, 1999. International Financial Statistics Yearbook. International Monetary Fund, Washington DC.

Kaen, F.R., Michalsen, D., 1997. The Effects of the Norwegian Banking Crisis on Norwegian Bank and Non-bank Stocks. Journal of Multinational Financial Management 7, 83-111.

Kang, J.K., Stulz, R.M., 1996. How Different Is Japanese Corporate Finance? An Investigation of the Information Content of New Security Issues. Review of Financial Studies 9, 109-140.

Kang, J.K., Stulz, R.M., 2000. Do Banking Shocks Affect Borrowing Firm Performance? An Analysis of the Japanese Experience. Journal of Business 73, 1-24.

Keeley, M.C., 1990. Deposit Insurance Risk and Market Power in Banking. American Economic Review 80, 1183-1200.

Kindleberger, C.P., 1996. Manias, Panics and Crashes: a History of Financial Crises. MacMillan, London.

King, R.G., Plosser, C.I., 1984. Money, Credit, and Prices in a Real Business Cycle. American Economic Review 74, 363-380.

La Porta, R., Lopez-de-Silanes, F., Shleifer, A., Vishny, R.W., 1998. Law and Finance. Journal of Political Economy 106, 1113-1155.

McKinnon, J., 1986. The Historical Development and Operational Form of Corporate Reporting Regulation in Japan. Garland Publishing, New York NY.

Morck, R., Nakamura, M., 1999. Banks and Control in Japan. Journal of Finance 54, 319-339.

Morck, R., Nakamura, M., 2000. Japanese Corporate Governance and Macroeconomic Problems. Working Paper. Harvard Institute of Economic Research.

Norli, Ø., 1998. Private Equity Financing and the Equity Flotation Method Choice: Theory and Evidence. Working Paper. University of Toronto.

Ongena, S., Smith, D.C., 2000. The Duration of Bank Relationships. Journal of Financial Economics Forthcoming.

Prowse, S., 1992. The Structure of Corporate Ownership in Japan. Journal of Finance 47, 1121-1140.

Rajan, R.G., Zingales, L., 1998. Which Capitalism? Lessons from the East Asian Crisis. Journal of Applied Corporate Finance 11, 40-48.

Rajan, R.G., Zingales, L., 2000. The Great Reversals: The Politics of Financial Development in the 20th Century. Working Paper. University of Chicago.

Royama, S., 2000. The Big Bang in Japanese Securities Markets. In: Hoshi, T. and Patrick, H. (Ed.), Crisis and Change in the Japanese Financial System. Kluwer Academic Press, Boston MA.

Slovin, M.B., Sushka, M.E., Polonchek, J.A., 1993. The Value of Bank Durability: Borrowers as Bank Stakeholders. Journal of Finance 48, 289-302.

Thompson, R., 1985. Conditioning the Return-Generating Process on Firm-Specific Events: A Discussion of Event Study Methods. Journal of Financial and Quantitative Analysis 20, 151-168.

Weinstein, D.E., Yafeh, Y., 1998. On the Costs of a Bank Centered Financial System: Evidence from the Changing Main Bank Relations in Japan. Journal of Finance 53, 635-672.

Yamori, N., Murakami, A., 1999. Does Bank Relationship Have an Economic Value? The Effect of Main Bank Failure on Client Firms. Economics Letters 65, 115-120. 


\section{TABLE 1. ANNUAL OVERVIEW OF TURNOVER IN BANK RELATIONSHIPS, NUMBER OF FIRMS}

\section{LISTING AND DELISTING ON THE OSLO STOCK EXCHANGE, AND NUMBER OF BANKRUPTCIES.}

This table lists, by year, the total number of firms listed on the Oslo Stock Exchange (OSE), the number of new bank relationships, the number of terminated bank relationships, the number of firms listing and delisting from the OSE, and the total number of firms declaring bankruptcy in Norway. A bank relationship in this table is a 'primary' bank relationship, as defined by the firm and reported in Kierulf's Handbook. We identify a firm as ending a relationship when it drops a bank from the list or replaces one bank with another. Information on bank relationships comes from Kierulf's Handbook, the total number of firms listed on the OSE, and the number of firms listing and delisting each year is provided by Oslo Børs Informasjon AS (OBI). Total bankruptcies are taken from the Statistical Yearbook of Norway.

\begin{tabular}{|c|c|c|c|c|c|}
\hline Year & $\begin{array}{l}\text { Firms listed } \\
\text { on the OSE }\end{array}$ & $\begin{array}{c}\text { Bank } \\
\text { relationships } \\
\text { started } \\
\end{array}$ & $\begin{array}{c}\text { Bank } \\
\text { relationships } \\
\text { terminated }\end{array}$ & $\begin{array}{c}\text { Bankruptcies } \\
\text { across all } \\
\text { firms } \\
\end{array}$ & $\begin{array}{c}\text { Delistings } \\
\text { from the OSE }\end{array}$ \\
\hline 1980 & 109 & 5 & 5 & 765 & 10 \\
\hline 1981 & 112 & 2 & 1 & 810 & 2 \\
\hline 1982 & 117 & 3 & 4 & 955 & 1 \\
\hline 1983 & 136 & 5 & 5 & 1,236 & 2 \\
\hline 1984 & 158 & 7 & 5 & 1,304 & 0 \\
\hline 1985 & 159 & 6 & 1 & 1,340 & 6 \\
\hline 1986 & 154 & 17 & 16 & 1,426 & 12 \\
\hline 1987 & 143 & 14 & 10 & 2,075 & 15 \\
\hline 1988 & 129 & 18 & 12 & 3,891 & 17 \\
\hline 1989 & 130 & 11 & 6 & 4,536 & 11 \\
\hline 1990 & 114 & 14 & 7 & 3,814 & 24 \\
\hline 1991 & 117 & 14 & 9 & 4,926 & 11 \\
\hline 1992 & 121 & 16 & 5 & 5,749 & 7 \\
\hline 1993 & 125 & 10 & 4 & 5,158 & 12 \\
\hline 1994 & 131 & 14 & 5 & 3,634 & 11 \\
\hline 1995 & 133 & 10 & 6 & 3,500 & 18 \\
\hline Mean & 129.5 & 10.4 & 6.3 & 2,820 & 9.9 \\
\hline
\end{tabular}




\section{TABLE 2. DISTRESS EVENTS AND NUMBER OF RELATIONSHIPS PER DISTRESSED BANK.}

This table lists the six event dates in our sample, a description of the event and the bank involved (in boldface), and the number of Oslo Stock Exchange (OSE)listed firms related and not related to the bank at the time of the distress announcement. Event dates correspond to the actual announcement date (if given in a report) or the trading day prior to the announcement in a newspaper. CBGF is the Commercial Bank Guarantee Fund; SBGF is Savings Bank Guarantee Fund; NOK is Norwegian Kroner (at the start of the crisis, 1 US $\$ \approx 6.5$ NOK); BISC is the Norwegian Banking Insurance and Securities Commission; and Norges Bank is the Norwegian Central Bank.

\begin{tabular}{|c|c|c|c|c|c|c|c|}
\hline \multirow[t]{2}{*}{ Distress Date } & \multirow[t]{2}{*}{ Distress Event (Information Source) } & \multicolumn{3}{|c|}{$\begin{array}{l}\text { Number (percentage) of firms } \\
\text { with a relationship with } \\
\text { distressed bank(s) }\end{array}$} & \multicolumn{3}{|c|}{$\begin{array}{l}\text { Number (percentage) of firms } \\
\text { with a relationship with other } \\
\text { banks }\end{array}$} \\
\hline & & Year -1 & Year 0 & Year +1 & Year -1 & Year 0 & Year +1 \\
\hline 03/18/88 & $\begin{array}{l}\text { Sunnmørsbanken must turn around losses in order to } \\
\text { sustain operations (OSE wire reports). }\end{array}$ & $\begin{array}{c}3 \\
(2.3)\end{array}$ & $\begin{array}{c}3 \\
(2.4)\end{array}$ & $\begin{array}{c}1 \\
(0.9)\end{array}$ & $\begin{array}{c}130 \\
(97.7)\end{array}$ & $\begin{array}{c}122 \\
(97.6)\end{array}$ & $\begin{array}{c}112 \\
(99.1)\end{array}$ \\
\hline $10 / 08 / 89$ & $\begin{array}{l}\text { BISC reports that Sparebanken Nord-Norge has lost its } \\
\text { capital. SBGF provides capital injection (SBGF } 1989 \\
\text { Annual Report). }\end{array}$ & $\begin{array}{c}1 \\
(0.8)\end{array}$ & $\begin{array}{c}2 \\
(1.8)\end{array}$ & $\begin{array}{c}1 \\
(0.9)\end{array}$ & $\begin{array}{c}124 \\
(99.2)\end{array}$ & $\begin{array}{c}111 \\
(98.2)\end{array}$ & $\begin{array}{c}110 \\
(99.1)\end{array}$ \\
\hline $12 / 11 / 90$ & $\begin{array}{l}\text { Report appears in business newspaper about financial } \\
\text { problems at Fokus Bank. Fokus neither acknowledges } \\
\text { nor denies report (Dagens Naringsliv). }\end{array}$ & $\begin{array}{c}10 \\
(8.9)\end{array}$ & $\begin{array}{c}10 \\
(9.0)\end{array}$ & $\begin{array}{c}9 \\
(9.0)\end{array}$ & $\begin{array}{c}103 \\
(91.2)\end{array}$ & $\begin{array}{c}101 \\
(91.0)\end{array}$ & $\begin{array}{c}91 \\
(91.0)\end{array}$ \\
\hline $12 / 20 / 90$ & $\begin{array}{l}\text { Christiania Bank makes upward adjustment in loss } \\
\text { estimate (OSE wire reports). }\end{array}$ & $\begin{array}{c}54 \\
(47.8)\end{array}$ & $\begin{array}{c}54 \\
(48.7)\end{array}$ & $\begin{array}{c}47 \\
(47.0)\end{array}$ & $\begin{array}{c}59 \\
(52.2)\end{array}$ & $\begin{array}{c}57 \\
(51.3)\end{array}$ & $\begin{array}{c}53 \\
(53.0)\end{array}$ \\
\hline $01 / 04 / 91$ & $\begin{array}{l}\text { Den norske Bank has made adjustments in loan loss } \\
\text { estimate } 1990 \text { (OSE wire reports). }\end{array}$ & $\begin{array}{c}62 \\
(55.9)\end{array}$ & $\begin{array}{c}59 \\
(59.0)\end{array}$ & $\begin{array}{c}60 \\
(56.6)\end{array}$ & $\begin{array}{c}49 \\
(54.1)\end{array}$ & $\begin{array}{c}41 \\
(41.0)\end{array}$ & $\begin{array}{c}46 \\
(43.4)\end{array}$ \\
\hline 06/17/91 & $\begin{array}{l}\text { CBGF receives requests from Den norkse Bank (NOK } \\
938.8 \mathrm{~m} \text { ) and Christiania Bank (NOK } 624.3 \mathrm{~m} \text { ) for } \\
\text { injection of preferred equity (Dagens Naeringsliv). }\end{array}$ & $\begin{array}{c}96 \\
(86.4)\end{array}$ & $\begin{array}{c}89 \\
(89.0)\end{array}$ & $\begin{array}{c}89 \\
(83.9)\end{array}$ & $\begin{array}{c}15 \\
(13.6)\end{array}$ & $\begin{array}{c}11 \\
(11.0)\end{array}$ & $\begin{array}{c}17 \\
(16.1)\end{array}$ \\
\hline
\end{tabular}




\section{Table 3. Cumulative Abnormal Returns, Distressed Banks}

Cumulative Abnormal Returns (CARs) to banks announcing distress. The Oslo Stock Exchange (OSE) market index is value-weighted index of returns on all firms listed on the OSE. The World Market Index (World) is a value weighted (by the US \$ value of market capitalization on July $1^{\text {st }}$, 1987) combination of the valueweighted indices of German, Japanese, UK, and US stocks. For the 6/17/91 event, the CARs for Den norske Bank and Christiania Bank are averaged and treated as one event. For the individual distress events, the pvalues reported in parentheses are based on a Wald test that the sum of daily abnormal returns within the event window are zero. The test is distributed $\chi^{2}(\mathrm{k})$, where $\mathrm{k}$ is the number of days in the window. For the Average Across All Events, the p-values are based on a t-test that assumes the returns are i.i.d. across the events. 
Table 3

\begin{tabular}{|c|c|c|c|c|c|}
\hline Bank (Event Date) & $\begin{array}{c}\text { Market } \\
\text { Index }\end{array}$ & & Even & Window & \\
\hline & & $(-10,-1)$ & $(0,+10)$ & $(-3,+3)$ & $(-1,+1)$ \\
\hline \multirow[t]{2}{*}{ Sunnmørsbanken $(03 / 18 / 88)$} & OSE & $\begin{array}{c}0.057 \\
(0.022)\end{array}$ & $\begin{array}{c}0.073 \\
(0.008)\end{array}$ & $\begin{array}{c}0.067 \\
(0.000)\end{array}$ & $\begin{array}{l}-0.028 \\
(0.001)\end{array}$ \\
\hline & World & $\begin{array}{c}0.059 \\
(0.019)\end{array}$ & $\begin{array}{c}0.067 \\
(0.012)\end{array}$ & $\begin{array}{c}0.070 \\
(0.000)\end{array}$ & $\begin{array}{l}-0.028 \\
(0.000)\end{array}$ \\
\hline \multirow[t]{2}{*}{ Fokus Bank (12/11/90) } & OSE & $\begin{array}{c}-0.031 \\
(0.199)\end{array}$ & $\begin{array}{c}-0.363 \\
(0.000)\end{array}$ & $\begin{array}{l}-0.173 \\
(0.000)\end{array}$ & $\begin{array}{l}-0.148 \\
(0.000)\end{array}$ \\
\hline & World & $\begin{array}{l}-0.037 \\
(0.129)\end{array}$ & $\begin{array}{l}-0.387 \\
(0.000)\end{array}$ & $\begin{array}{l}-0.239 \\
(0.000)\end{array}$ & $\begin{array}{l}-0.192 \\
(0.000)\end{array}$ \\
\hline \multirow[t]{2}{*}{ Christiania Bank (12/20/90) } & OSE & $\begin{array}{l}-0.024 \\
(0.256)\end{array}$ & $\begin{array}{l}-0.061 \\
(0.011)\end{array}$ & $\begin{array}{l}-0.082 \\
(0.000)\end{array}$ & $\begin{array}{l}-0.074 \\
(0.000)\end{array}$ \\
\hline & World & $\begin{array}{l}-0.107 \\
(0.000)\end{array}$ & $\begin{array}{l}-0.074 \\
(0.005)\end{array}$ & $\begin{array}{l}-0.095 \\
(0.000)\end{array}$ & $\begin{array}{l}-0.115 \\
(0.000)\end{array}$ \\
\hline \multirow[t]{2}{*}{ Den norske Bank (01/04/91) } & OSE & $\begin{array}{l}-0.123 \\
(0.000)\end{array}$ & $\begin{array}{l}-0.040 \\
(0.075)\end{array}$ & $\begin{array}{l}-0.124 \\
(0.000)\end{array}$ & $\begin{array}{l}-0.085 \\
(0.000)\end{array}$ \\
\hline & World & $\begin{array}{l}-0.134 \\
(0.000)\end{array}$ & $\begin{array}{l}-0.069 \\
(0.002)\end{array}$ & $\begin{array}{l}-0.108 \\
(0.000)\end{array}$ & $\begin{array}{l}-0.104 \\
(0.000)\end{array}$ \\
\hline \multirow[t]{2}{*}{ Christiania Bank (06/17/91) } & OSE & $\begin{array}{c}0.229 \\
(0.000)\end{array}$ & $\begin{array}{c}0.000 \\
(0.990)\end{array}$ & $\begin{array}{l}-0.150 \\
(0.000)\end{array}$ & $\begin{array}{l}-0.064 \\
(0.000)\end{array}$ \\
\hline & World & $\begin{array}{c}0.260 \\
(0.000)\end{array}$ & $\begin{array}{c}0.028 \\
(0.316)\end{array}$ & $\begin{array}{l}-0.120 \\
(0.000)\end{array}$ & $\begin{array}{l}-0.053 \\
(0.000)\end{array}$ \\
\hline \multirow[t]{2}{*}{ Den norske Bank (06/17/91) } & OSE & $\begin{array}{c}0.149 \\
(0.000)\end{array}$ & $\begin{array}{l}-0.102 \\
(0.020)\end{array}$ & $\begin{array}{l}-0.303 \\
(0.000)\end{array}$ & $\begin{array}{l}-0.149 \\
(0.000)\end{array}$ \\
\hline & World & $\begin{array}{c}0.197 \\
(0.000)\end{array}$ & $\begin{array}{c}-0.067 \\
(0.188)\end{array}$ & $\begin{array}{l}-0.259 \\
(0.000)\end{array}$ & $\begin{array}{l}-0.128 \\
(0.000)\end{array}$ \\
\hline \multirow[t]{2}{*}{ Average Across All Events } & OSE & $\begin{array}{c}0.013 \\
(0.808)\end{array}$ & $\begin{array}{l}-0.088 \\
(0.290)\end{array}$ & $\begin{array}{l}-0.107 \\
(0.097)\end{array}$ & $\begin{array}{l}-0.088 \\
(0.011)\end{array}$ \\
\hline & World & $\begin{array}{c}0.001 \\
(0.979)\end{array}$ & $\begin{array}{l}-0.096 \\
(0.277)\end{array}$ & $\begin{array}{l}-0.112 \\
(0.100)\end{array}$ & $\begin{array}{l}-0.106 \\
(0.015)\end{array}$ \\
\hline \multirow[t]{2}{*}{$\begin{array}{c}\text { SUR Regression Across All } \\
\text { Events }\end{array}$} & OSE & $\begin{array}{c}-0.024 \\
(0.561)\end{array}$ & $\begin{array}{l}-0.105 \\
(0.015)\end{array}$ & $\begin{array}{c}-0.136 \\
(0.000)\end{array}$ & $\begin{array}{l}-0.096 \\
(0.000)\end{array}$ \\
\hline & World & $\begin{array}{l}-0.036 \\
(0.370)\end{array}$ & $\begin{array}{c}-0.118 \\
(0.005)\end{array}$ & $\begin{array}{l}-0.137 \\
(0.000)\end{array}$ & $\begin{array}{l}-0.116 \\
(0.000)\end{array}$ \\
\hline
\end{tabular}




\section{Table 4. Cumulative Abnormal Returns, Related Firms}

Cumulative Abnormal Returns (CARs) on an equal-weighted portfolio of related firms' stocks. $\mathrm{N}$ is the number of stocks in the portfolio. The Oslo Stock Exchange (OSE) market index is value-weighted. The World Market Index (World) is a value weighted (by the US \$ value of market capitalization on July $1^{\text {st }}$, 1987) combination of the value-weighted indices of German, Japanese, UK, and US stocks. The Firmweighted Difference Portfolio averages the differences between portfolios of related and unrelated firms. The portfolios are created by first weighting each return by the total number of related firms. For the individual distress events and for the Firm-weighted Difference Portfolio, the p-values reported in parentheses are based on a Wald test that the sum of daily abnormal returns within the event window are zero. The test is distributed $\chi^{2}(\mathrm{k})$, where $\mathrm{k}$ is the number of days in the window. For the average across all events, the $p$-values are based on a bootstrapped distribution (150 draws) that preserves the cross-sectional error structure of firms sharing a common event and preserves the error structure of the overlapping time period between event estimation windows. 
Table 4

\begin{tabular}{|c|c|c|c|c|c|c|}
\hline Banks (Event Date) & $\mathrm{N}$ & Market Index & & Event & Window & \\
\hline & & & $(-10,-1)$ & $(0,+10)$ & $(-3,+3)$ & $(-1,+1)$ \\
\hline \multirow[t]{2}{*}{$\begin{array}{c}\text { Sunnmørsbanken } \\
(03 / 18 / 88)\end{array}$} & 3 & OSE & $\begin{array}{l}-0.070 \\
(0.006)\end{array}$ & $\begin{array}{c}0.088 \\
(0.002)\end{array}$ & $\begin{array}{c}0.142 \\
(0.000)\end{array}$ & $\begin{array}{l}-0.079 \\
(0.000)\end{array}$ \\
\hline & & World & $\begin{array}{l}-0.063 \\
(0.011)\end{array}$ & $\begin{array}{c}0.115 \\
(0.000)\end{array}$ & $\begin{array}{c}0.150 \\
(0.000)\end{array}$ & $\begin{array}{l}-0.064 \\
(0.000)\end{array}$ \\
\hline \multirow[t]{2}{*}{$\begin{array}{l}\text { Sparebanken Nord-Norge } \\
(10 / 08 / 89)\end{array}$} & 2 & OSE & $\begin{array}{l}-0.179 \\
(0.000)\end{array}$ & $\begin{array}{c}-0.274 \\
(0.000)\end{array}$ & $\begin{array}{l}-0.076 \\
(0.019)\end{array}$ & $\begin{array}{l}-0.256 \\
(0.000)\end{array}$ \\
\hline & & World & $\begin{array}{c}-0.181 \\
(0.000)\end{array}$ & $\begin{array}{c}-0.308 \\
(0.000)\end{array}$ & $\begin{array}{c}-0.102 \\
(0.000)\end{array}$ & $\begin{array}{l}-0.263 \\
(0.000)\end{array}$ \\
\hline \multirow[t]{2}{*}{ Fokus Bank (12/11/90) } & 9 & OSE & $\begin{array}{c}0.011 \\
(0.057)\end{array}$ & $\begin{array}{c}0.028 \\
(0.001)\end{array}$ & $\begin{array}{l}-0.019 \\
(0.000)\end{array}$ & $\begin{array}{l}-0.023 \\
(0.000)\end{array}$ \\
\hline & & World & $\begin{array}{c}0.015 \\
(0.050)\end{array}$ & $\begin{array}{c}0.000 \\
(0.972)\end{array}$ & $\begin{array}{l}-0.066 \\
(0.000)\end{array}$ & $\begin{array}{l}-0.062 \\
(0.000)\end{array}$ \\
\hline \multirow[t]{2}{*}{ Christiania Bank (12/20/90) } & 49 & OSE & $\begin{array}{c}0.015 \\
(0.001)\end{array}$ & $\begin{array}{l}-0.005 \\
(0.408)\end{array}$ & $\begin{array}{c}0.021 \\
(0.000)\end{array}$ & $\begin{array}{c}0.004 \\
(0.187)\end{array}$ \\
\hline & & World & $\begin{array}{l}-0.036 \\
(0.000)\end{array}$ & $\begin{array}{c}-0.014 \\
(0.039)\end{array}$ & $\begin{array}{c}0.011 \\
(0.003)\end{array}$ & $\begin{array}{l}-0.022 \\
(0.000)\end{array}$ \\
\hline \multirow[t]{2}{*}{$\begin{array}{l}\text { Den norske Bank } \\
(01 / 04 / 91)\end{array}$} & 52 & OSE & $\begin{array}{l}-0.035 \\
(0.000)\end{array}$ & $\begin{array}{c}0.052 \\
(0.000)\end{array}$ & $\begin{array}{c}-0.022 \\
(0.000)\end{array}$ & $\begin{array}{l}-0.016 \\
(0.000)\end{array}$ \\
\hline & & World & $\begin{array}{l}-0.043 \\
(0.000)\end{array}$ & $\begin{array}{c}0.033 \\
(0.000)\end{array}$ & $\begin{array}{c}-0.012 \\
(0.037)\end{array}$ & $\begin{array}{l}-0.028 \\
(0.000)\end{array}$ \\
\hline \multirow[t]{2}{*}{$\begin{array}{c}\text { Christiania Bank and Den } \\
\text { norske Bank }(06 / 17 / 91)\end{array}$} & 75 & OSE & $\begin{array}{c}0.016 \\
(0.000)\end{array}$ & $\begin{array}{c}-0.004 \\
(0.286)\end{array}$ & $\begin{array}{c}0.000 \\
(0.812)\end{array}$ & $\begin{array}{l}-0.010 \\
(0.000)\end{array}$ \\
\hline & & World & $\begin{array}{c}0.032 \\
(0.000)\end{array}$ & $\begin{array}{c}0.008 \\
(0.222)\end{array}$ & $\begin{array}{c}0.015 \\
(0.001)\end{array}$ & $\begin{array}{l}-0.003 \\
(0.028)\end{array}$ \\
\hline \multirow[t]{2}{*}{$\begin{array}{c}\text { Average Across All Related } \\
\text { Firms }\end{array}$} & 169 & OSE & $\begin{array}{c}0.010 \\
(0.366)\end{array}$ & $\begin{array}{c}0.013 \\
(0.213)\end{array}$ & $\begin{array}{c}0.009 \\
(0.493)\end{array}$ & $\begin{array}{l}-0.005 \\
(0.280)\end{array}$ \\
\hline & & World & $\begin{array}{l}-0.001 \\
(0.120)\end{array}$ & $\begin{array}{c}0.014 \\
(0.540)\end{array}$ & $\begin{array}{c}0.017 \\
(0.800)\end{array}$ & $\begin{array}{l}-0.014 \\
(0.020)\end{array}$ \\
\hline \multirow[t]{2}{*}{$\begin{array}{l}\text { Firm-weighted Difference } \\
\text { Portfolio }\end{array}$} & 6 & OSE & $\begin{array}{c}0.001 \\
(0.935)\end{array}$ & $\begin{array}{c}0.017 \\
(0.391)\end{array}$ & $\begin{array}{c}0.017 \\
(0.565)\end{array}$ & $\begin{array}{l}-0.014 \\
(0.253)\end{array}$ \\
\hline & & World & $\begin{array}{c}0.003 \\
(0.863)\end{array}$ & $\begin{array}{c}0.020 \\
(0.286)\end{array}$ & $\begin{array}{c}0.017 \\
(0.549)\end{array}$ & $\begin{array}{l}-0.017 \\
(0.227)\end{array}$ \\
\hline
\end{tabular}




\section{TABLE 5. EQUITY ISSUANCE BEHAVIOR OF NORWEGIAN AND JAPANESE PUBLICLY-LISTED FIRMS, 1985-1996.}

This table lists the number of non-financial, publicly-listed firms in Norway and Japan issuing equity or equity-type securities, and the total value of offerings relative to total market capitalization, for the years 1985-1996. The seasoned Norwegian issues are provided by Øyvind Norli and consist of all seasoned public, rights, and private equity offerings made by non-financial firms listed on the Oslo Stock Exchange (OSE), based upon OSE Annual Reports (see Norli, 1998). The public equity and rights category includes initial public offerings, taken from Helland and Samuelson (1999). To calculate the Norwegian ratio of total equity raised to market capitalization, we use data from the OSE Annual Statistics. The Japanese issues consist of all initial and seasoned public, rights, and private equity and all convertible bond issues (both domestically and abroad) made by non-financial firms listed on Japanese stock exchanges taken from the Tokyo Stock Exchange (TSE)'s Annual Securities Statistics. We use data from the TSE Fact Book to calculate the Japanese ratio of the total equity raised to market capitalization, limiting the sample to firms listed on the TSE.

\begin{tabular}{|c|c|c|c|c|c|c|c|c|c|c|c|}
\hline & \multicolumn{5}{|c|}{ Norwegian Firms } & \multicolumn{6}{|c|}{ Japanese Firms } \\
\hline & $\begin{array}{l}\text { Public } \\
\text { and } \\
\text { rights } \\
\text { equity }\end{array}$ & $\begin{array}{l}\text { Private } \\
\text { equity }\end{array}$ & $\begin{array}{l}\text { Total } \\
\text { equity- } \\
\text { type } \\
\text { issues }\end{array}$ & $\begin{array}{c}\text { Issues } \\
\text { over } \\
\text { listed } \\
\text { firms }\end{array}$ & $\begin{array}{c}\text { Amount } \\
\text { raised over } \\
\text { market cap. }\end{array}$ & $\begin{array}{l}\text { Public } \\
\text { and } \\
\text { rights } \\
\text { equity }\end{array}$ & $\begin{array}{l}\text { Private } \\
\text { equity }\end{array}$ & $\begin{array}{c}\text { Convertible } \\
\text { bonds }\end{array}$ & $\begin{array}{l}\text { Total } \\
\text { equity } \\
\text {-type } \\
\text { issues }\end{array}$ & $\begin{array}{l}\text { Issues } \\
\text { over } \\
\text { listed } \\
\text { firms }\end{array}$ & $\begin{array}{l}\text { Amount } \\
\text { raised over } \\
\text { market cap. }\end{array}$ \\
\hline 1985 & 41 & 6 & 30 & 0.29 & 0.05 & 103 & 18 & 208 & 329 & 0.18 & 0.01 \\
\hline 1986 & 23 & 12 & 28 & 0.23 & 0.04 & 66 & 16 & 189 & 271 & 0.15 & 0.01 \\
\hline 1987 & 19 & 10 & 22 & 0.20 & 0.03 & 72 & 22 & 313 & 407 & 0.21 & 0.02 \\
\hline 1988 & 19 & 18 & 30 & 0.28 & 0.04 & 125 & 23 & 322 & 470 & 0.24 & 0.02 \\
\hline 1989 & 26 & 19 & 43 & 0.35 & 0.04 & 179 & 22 & 348 & 549 & 0.27 & 0.03 \\
\hline 1990 & 24 & 20 & 37 & 0.36 & 0.04 & 125 & 21 & 161 & 307 & 0.15 & 0.02 \\
\hline 1991 & 19 & 9 & 28 & 0.25 & 0.03 & 60 & 19 & 103 & 182 & 0.09 & 0.01 \\
\hline 1992 & 25 & 6 & 23 & 0.25 & 0.05 & 12 & 22 & 50 & 84 & 0.04 & 0.00 \\
\hline 1993 & 39 & 21 & 57 & 0.46 & 0.06 & 5 & 11 & 128 & 144 & 0.07 & 0.01 \\
\hline 1994 & 33 & 11 & 39 & 0.33 & 0.05 & 18 & 16 & 169 & 203 & 0.09 & 0.01 \\
\hline 1995 & 58 & 28 & 76 & 0.53 & 0.03 & 9 & 17 & 62 & 88 & 0.04 & 0.00 \\
\hline 1996 & 55 & 30 & 81 & 0.49 & 0.02 & 37 & 17 & 184 & 238 & 0.10 & 0.01 \\
\hline Avg. & 32 & 16 & 41 & 0.33 & 0.04 & 68 & 19 & 186 & 273 & 0.14 & 0.01 \\
\hline
\end{tabular}




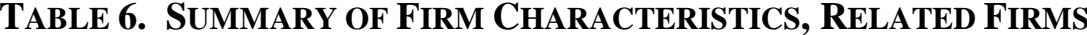

There are 169 related firm observations in the sample. SALES is year-end sales, measured in millions of 1990 Norwegian Kroner. AGE is measured relative to the founding date of the firm (in years). DEBT is the book value of debt, divided by the sum of year-end market value of equity and book value of debt. DRAWN CREDIT is the book value of drawn lines of credit, divided by the sum of year-end market value of equity and book value of debt. CASH FLOW is the ratio of net operating income and normal depreciation to book value of assets. TERMINATION PROPENSITY is the average forecasted likelihood (truncated at a 100\%) that a firm terminates a relationship, conditional on survival through the year before bank distress (see Model 6.4 in Ongena and Smith (2000)). HEALTHY BANK equals one when a firm maintains a relationship with another bank previously unaffected by distress, and zero otherwise. INTERNATIONAL BANK takes the value of one when a firm maintains a relationship with a Non-Norwegian bank, and zero otherwise. BANKER ON BOARD equals one when a manager of the distressed bank sits on the firm's board and zero otherwise. EQUITY ISSUE is the ratio of equity issued, publicly and privately, by the firm in the two years prior to bank distress to the book value of assets.

\begin{tabular}{|c|c|c|c|c|c|}
\hline & Mean & Standard Deviation & Minimum & Median & Maximum \\
\hline SALES & $\operatorname{Kr} 2,785.138$ & $\mathrm{Kr} 7,210.851$ & 0 & Kr 551.077 & $58,976.552$ \\
\hline AGE & 57.934 & 40.027 & 0 & 63 & 149 \\
\hline DEBT & 0.559 & 0.255 & 0 & 0.597 & 0.983 \\
\hline CASH FLOW & 0.092 & 0.111 & -0.400 & 0.099 & 0.357 \\
\hline DRAWN CREDIT & 0.021 & 0.046 & 0 & 0 & 0.277 \\
\hline TERMINATION & 8.409 & 9.369 & 0 & 6.799 & 100 \\
\hline $\begin{array}{c}\text { PROPENSITY } \\
\text { HEALTHY BANK }\end{array}$ & 0.254 & 0.436 & 0 & 0 & 1 \\
\hline INTERNATIONAL BANK & 0.082 & 0.276 & 0 & 0 & 1 \\
\hline BANKER ON BOARD & 0.023 & 0.152 & 0 & 0 & 1 \\
\hline EQUITY ISSUE & 0.070 & 0.128 & 0 & 0.016 & 0.832 \\
\hline
\end{tabular}




\section{TABLE 7. Cross SECTIONAL EXAMination OF Firm RElated CARS}

The number of observations is 169. The dependent variable is the three (seven)-day Cumulative Abnormal Return for the firm (in percent). LN SALES is the logarithm of year-end sales, measured in 1979 Norwegian Kroner. AGE is measured relative to the founding date of the firm (in years) at the beginning of the crisis in 1988. DEBT is the book value of debt, divided by the sum of year-end market value of equity and book value of debt. DRAWN CREDIT is the book value of drawn lines of credit, divided by the sum of year-end market value of equity and book value of debt. CASH FLOW is the ratio of net operating income and normal depreciation to book value of assets. TERMINATION PROPENSITY is the average forecasted likelihood (truncated at a 100\%) that a firm terminates a relationship, conditional on survival through the year before bank distress (see Model 6.4 in Ongena and Smith (2000)). HEALTHY BANK equals one when a firm maintains a relationship with another bank previously unaffected by distress, and zero otherwise. INTERNATIONAL BANK takes the value of one when a firm maintains a relationship with a non-Norwegian bank and zero otherwise. BANKERS ON BOARD equals one when a manager of the distressed bank sits on the firm's board and zero otherwise. EQUITY ISSUE is the ratio of equity issued, publicly and privately, by the firm in the two years prior to bank distress to book value of assets.

BANKCAR is the three (seven)-day CAR for the bank (in percent). TIME is measured relative to the first distress announcement (the logarithm of the number of days). Coefficients are listed on the first row in each cell with reported below p-values based on a bootstrapped distribution (150 draws) that preserves the crosssectional error structure of firms sharing a common event and preserves the error structure of the overlapping time period between event estimation windows. 


\begin{tabular}{|c|c|c|c|c|c|c|}
\hline Event window & & $(-1,+1)$ & & & $(-3,+3)$ & \\
\hline Model & (1a) & (2a) & (3a) & (1b) & (2b) & $(3 b)$ \\
\hline Intercept & $\begin{array}{l}-2.688 \\
(0.180)\end{array}$ & $\begin{array}{l}-2.596 \\
(0.153)\end{array}$ & $\begin{array}{l}-5.214 \\
(1.163)\end{array}$ & $\begin{array}{l}3.446 \\
(0.293)\end{array}$ & $\begin{array}{c}3.427 \\
(0.280)\end{array}$ & $\begin{array}{l}12.462 \\
(0.233)\end{array}$ \\
\hline LN SALES & $\begin{array}{c}0.098 \\
(0.300)\end{array}$ & $\begin{array}{c}0.130 \\
(0.210)\end{array}$ & $\begin{array}{c}-0.100 \\
(0.426)\end{array}$ & $\begin{array}{c}0.146 \\
(0.440)\end{array}$ & $\begin{array}{c}0.068 \\
(0.420)\end{array}$ & $\begin{array}{c}0.327 \\
(0.293)\end{array}$ \\
\hline AGE & $\begin{array}{c}0.000 \\
(0.540)\end{array}$ & $\begin{array}{l}-0.000 \\
(0.413)\end{array}$ & $\begin{array}{l}-0.004 \\
(0.012)\end{array}$ & $\begin{array}{l}-0.029 \\
(0.093)\end{array}$ & $\begin{array}{c}-0.027 \\
(0.100)\end{array}$ & $\begin{array}{c}-0.022 \\
(0.180)\end{array}$ \\
\hline DEBT & $\begin{array}{c}0.308 \\
(0.513)\end{array}$ & & & $\begin{array}{c}-3.192 \\
(0.286)\end{array}$ & & \\
\hline CASH FLOW & $\begin{array}{c}0.985 \\
(0.446)\end{array}$ & $\begin{array}{c}0.566 \\
(0.546)\end{array}$ & $\begin{array}{c}0.536 \\
(0.473)\end{array}$ & $\begin{array}{c}4.172 \\
(0.320)\end{array}$ & $\begin{array}{c}3.935 \\
(0.313)\end{array}$ & $\begin{array}{l}5.519 \\
(0.266)\end{array}$ \\
\hline DRAWN CREDIT & & $\begin{array}{l}-5.146 \\
(0.380)\end{array}$ & $\begin{array}{l}-6.499 \\
(0.353)\end{array}$ & & $\begin{array}{l}-55.891 \\
(0.066)\end{array}$ & $\begin{array}{l}-53.276 \\
(0.013)\end{array}$ \\
\hline $\begin{array}{l}\text { TERMINATION } \\
\text { PROPENSITY }\end{array}$ & $\begin{array}{c}0.020 \\
(0.306)\end{array}$ & $\begin{array}{c}0.023 \\
(0.326)\end{array}$ & $\begin{array}{c}0.017 \\
(0.393)\end{array}$ & $\begin{array}{c}0.020 \\
(0.553)\end{array}$ & $\begin{array}{c}0.024 \\
(0.400)\end{array}$ & $\begin{array}{c}0.022 \\
(0.406)\end{array}$ \\
\hline HEALTHY BANK & $\begin{array}{l}-0.740 \\
(0.293)\end{array}$ & $\begin{array}{l}-0.692 \\
(0.320)\end{array}$ & $\begin{array}{c}0.523 \\
(0.373)\end{array}$ & $\begin{array}{l}-2.925 \\
(0.100)\end{array}$ & $\begin{array}{l}-2.250 \\
(0.160)\end{array}$ & $\begin{array}{l}-2.751 \\
(0.113)\end{array}$ \\
\hline $\begin{array}{l}\text { INTERNATIONAL } \\
\text { BANK }\end{array}$ & $\begin{array}{l}-3.236 \\
(0.073)\end{array}$ & $\begin{array}{l}-3.368 \\
(0.053)\end{array}$ & $\begin{array}{l}-4.076 \\
(0.040)\end{array}$ & $\begin{array}{c}2.416 \\
(0.186)\end{array}$ & $\begin{array}{c}1.082 \\
(0.273)\end{array}$ & $\begin{array}{c}1.447 \\
(0.260)\end{array}$ \\
\hline BANKER ON BOARD & $\begin{array}{l}-0.214 \\
(0.473)\end{array}$ & $\begin{array}{l}-0.380 \\
(0.473)\end{array}$ & $\begin{array}{l}-0.549 \\
(0.453)\end{array}$ & $\begin{array}{l}-2.564 \\
(0.346)\end{array}$ & $\begin{array}{l}-4.064 \\
(0.206)\end{array}$ & $\begin{array}{l}-4.184 \\
(0.206)\end{array}$ \\
\hline EQUITY ISSUE & $\begin{array}{c}7.731 \\
(0.060)\end{array}$ & $\begin{array}{c}7.557 \\
(0.080)\end{array}$ & $\begin{array}{c}4.311 \\
(0.200)\end{array}$ & $\begin{array}{l}10.591 \\
(0.080)\end{array}$ & $\begin{array}{c}9.065 \\
(0.113)\end{array}$ & $\begin{array}{l}12.475 \\
(0.060)\end{array}$ \\
\hline BANKCAR & & & $\begin{array}{c}0.638 \\
(0.013)\end{array}$ & & & $\begin{array}{c}0.108 \\
(0.366)\end{array}$ \\
\hline CRISIS LENGTH & & & $\begin{array}{c}1.742 \\
(0.120)\end{array}$ & & & $\begin{array}{c}-1.557 \\
(0.340)\end{array}$ \\
\hline Adjusted-R ${ }^{2}$ & -0.024 & -0.023 & 0.014 & -0.010 & 0.036 & 0.044 \\
\hline
\end{tabular}




\section{FIGURE 1. MARKET INDICES}

The Oslo Stock Exchange (OSE) and the OSE Bank Index are value-weighted (Source: OBI). The World Market Index is a value weighted (by the US \$ value of market capitalization on July $1^{\text {st }}$, 1987) combination of the value-weighted indices of German, Japanese, UK, and US stocks (Source: Datastream). Oil Price (Brent) is the average month ending price of Brent Blend North Sea Crude Oil, in US dollars. \% $\triangle$ Real GDP is the percentage growth rate in GDP, deflated by the Norwegian CPI. \% $\%$ Real Loans is the percentage increase in loans to businesses, households and municipalities by financial institutions, deflated by the Norwegian CPI. \% Loan Losses are commercial bank loan losses as a percentage of total commercial bank assets (Source: The Statistical Yearbook of Norway).

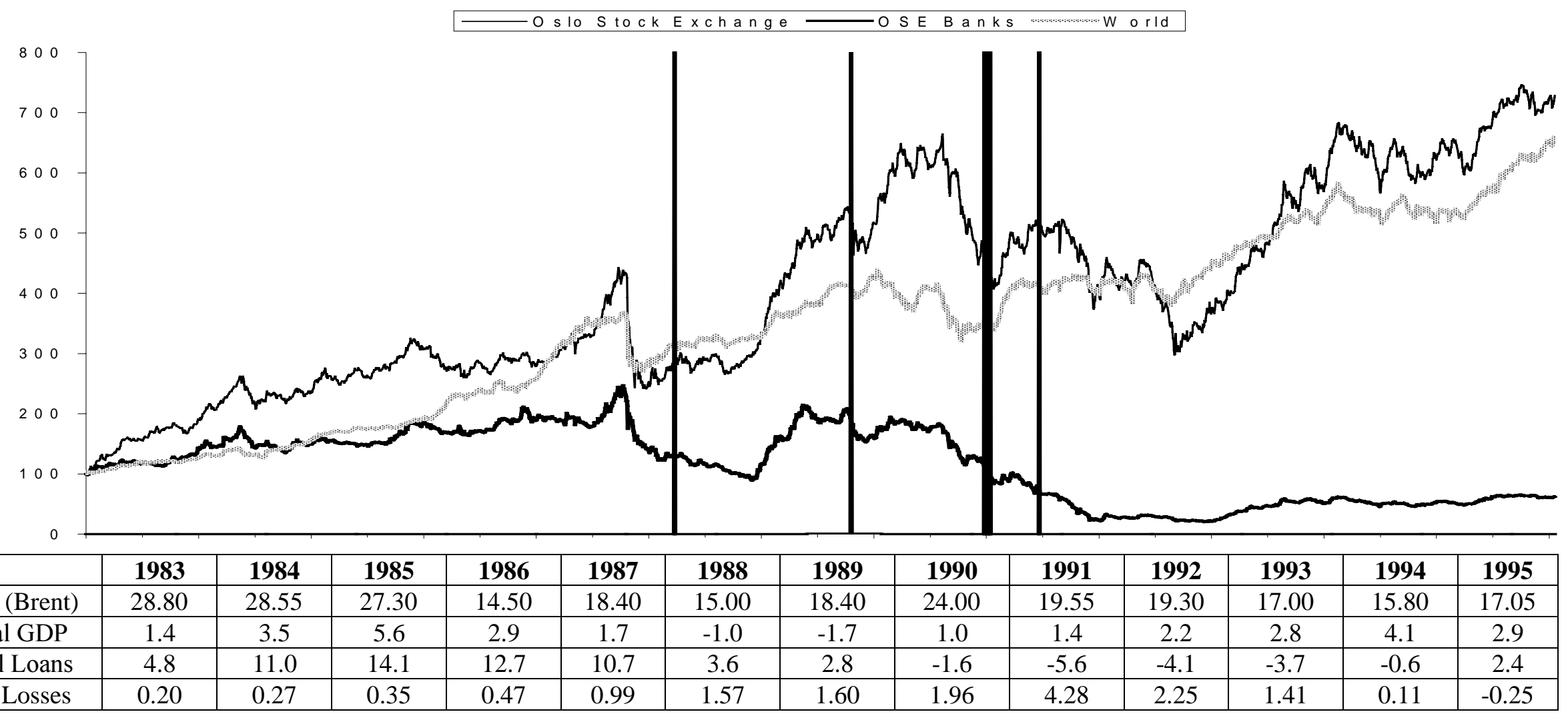




\section{Notes}

${ }^{1}$ In 1994, financial institutions provided $92 \%$ of all debt to the commercial sector, with banks accounting for $62 \%$ of the total (Source: Statistical Yearbook of Norway, 1996). According to Ongena and Smith (2000), 75\% of publicly-listed firms in Norway maintain a relationship with only one bank.

${ }^{2}$ For descriptions of the corporate governance structures of East Asian firms, see Allen and Gale (2000), Dinç (2000), and Claessens, Djankov and Lang (2000). Bøhren and Ødegaard (2000) provide a detailed overview of the corporate governance system in Norway.

${ }^{3}$ Djankov, et al. (2000) find that announcements of bank nationalizations and takeovers by foreign banks lead to borrower stock price increases.

${ }^{4}$ So-called "interest rate declarations" set upper limits on average bank loan rates, while restrictive reserve requirements, regulations requiring banks to invest in government bonds, and direct controls on lending by state-owned banks facilitated the rationing of credit at artificially low loan rates. ${ }^{5}$ Seven foreign banks were permitted to open subsidiaries. These included three US banks (Chase Manhattan, Citibank, and Manufacturers Hanover Trust), three French banks (Banque Indosuez, Banque Nationale de Paris, and Banque Paribas), and one English bank (Samuel Montague). Oslobanken, the first Norwegian commercial bank to be created since 1961, received formal permission to begin operations on March 30, 1984 (Årsmelding fra Bankinspeksjonen, 1984). By 1986, five newly-created domestic commercial banks operated in Norway.

${ }^{6}$ See Table 476, “Åpnede konkurser etter næring,” Statistical Yearbook of Norway, 1996.

${ }^{7}$ Early in the crisis, the chairman of Norway's central bank, Hermod Skånland, attributed high loan losses to "a combination of bad banking, bad policies, and bad luck" (Euromoney, 9/1/89). In September 1990, the BISC appointed a commission to investigate whether the behavior of some bank managers during the crisis was criminally fraudulent. By 1995, the committee had completed investigations into 11 financial institutions. The committee found indications of possible criminal acts or negligence in at least four of the institutions. However no formal charges were ever brought against any institution.

${ }^{8}$ See "Sikker som banken," Aftenposten, 3/16/90.

${ }^{9}$ According to the BISC, problems in the banking sector, exacerbated by credit rating downgrades, led to a decline in the amount of foreign funds available to Norwegian banks. A confidential report produced in December 1990 by the BISC for the Ministry of Finance stated, "There is a clear cut risk of a systemic crisis among other things as a result of the difficulties in international financial markets" (Annual Report 1991, BISC, p. 4). By the third quarter of 1991, Den norske Bank was forced to abandon plans for a new equity issue, weakening further its capital position.

${ }^{10}$ See "Staten bør ikke hjelpe bankene," Dagens Naringsliv, 10/26/89.

${ }^{11}$ See "Bankers trøst," Dagens Naringsliv, 1/29/91.

${ }^{12}$ See "Fokus to Get More Capital After Big Loss," The Wall Street Journal Europe, 8/26/91, and "State Takeover of Christiania Is in Prospect," The Wall Street Journal Europe, 10/15/91.

${ }^{13}$ As of September 2000, the state owned $60.4 \%$ of Den norske Bank and $36.4 \%$ of Christiania Bank. The entire state share in Christiania Bank was sold to Nordic Baltic Holding company on October 16, 2000.

${ }^{14}$ All firms listed on the OSE must provide annual information on their "primary" bank relationships, up to a maximum of four, as part of the listing requirement. A primary bank connection typically involves short and long-term lending, as well as the frequent purchase of deposit, cash management, foreign exchange, and risk management services.

${ }^{15}$ The pattern in bank relationship terminations suggests that firms switched out of distressed banks prior to the beginning of the banking crisis. This turns out not to be the case. Only three of the 46 
bank relationship relationships terminated during the 1986-88 period were with one of the original troubled banks. Most of the terminations were with international banks $(24 \%)$ or with one of Norway's two largest banks, Christiania Bank or Den norske Bank (59\%).

${ }^{16}$ The OBI stock price data set contains some recording errors. For the results reported in this paper, we record as "missing" realized daily returns in absolute value larger than $100 \%$. Our results are unaffected when we alter the cutoff imposed by this screen.

${ }^{17}$ I.e., we construct the t-test assuming the CAR's are i.i.d. and

$$
\frac{\operatorname{CAR}^{\mathrm{b}}(-\mathrm{t},+\mathrm{t})}{\left(\frac{\hat{\sigma}^{\mathrm{b}}}{\sqrt{6}}\right)} \sim \mathrm{t}(6-1)
$$

with,

$$
\hat{\sigma}^{b}(-t, t)=\left(\frac{6 \sum_{i=1}^{6}\left(\sum_{k=-t}^{t} \hat{\gamma}_{i k}^{b}\right)^{2}-\left(\sum_{i=1}^{6} \sum_{k=-t}^{t} \hat{\gamma}_{i k}^{b}\right)^{2}}{6(6-1)}\right)^{1 / 2} .
$$

${ }^{18}$ This average is considerably smaller (in absolute value) than the mean CAR of $-7.4 \%$, measured across the six event portfolios. This is because the portfolio CARs do not reflect the number of firms used to calculate the portfolio. The first three events involve only 14 related firms, while the latter three events impact 176 related firms. On a firm-weighted basis, the latter abnormal return estimates dominate. The 14 firms related to the first three distress events are smaller, younger and have maintained a shorter bank relationship with the distressed bank, than the firms related to the later distressed banks. We return to comparing the characteristics of the firms in Section 6. ${ }^{19}$ Hoshi and Kashyap (2000), Dinç (2000), and Hoshi and Patrick (2000) provide excellent overviews of the Japanese financial crisis.

${ }^{20}$ Loan loss numbers derived from the table "Loss on Disposal of Bad Loans of All Banks," Financial Services Agency (FSA), http://www.fsa.go.jpVnews/newse/e20000728-1b.html\#table3. Non-performing loan estimates based upon loans classified into categories II-IV by the Japanese Ministry of Finance self-assessment standards of asset quality. See http://www.fsa.go.jpVnews/newse/e20000728-1a.html.

${ }^{21}$ See "Table 9: Loan Losses, 1985-1992," Norges Bank Economic Bulletin, March 1993, page 48 and Figure 1 below.

${ }^{22}$ See "Rickety Japanese Banks: As Borrowers Collapse Is New Bailout Needed?," The New York Time, 9/8/00 and "BoJ says banks face further squeeze," Financial Times, 10/3/00.

${ }^{23}$ Japanese banks have been instrumental in corporate control since at least the Meiji government of the late $19^{\text {th }}$ century. For perspectives on the historical development of the Japanese financial system, see McKinnon (1986), Morck and Nakamura (2000), and Rajan and Zingales (2000).

${ }^{24}$ Banks obtain their control through two pervasive ownership structures in Japan: cross-ownership, where companies hold shares of each other's equity, and "pyramiding", where one company 
controls another company by holding substantial blocks of the voting equity. Oftentimes, these ownership structures are part of a financial keiretsu, defined to be a grouping of cross-held companies with a bank at its center, organized to guarantee "stable shareholding" (Morck and Nakamura (1999)).

${ }^{25}$ This is partly due to the fact that Japanese banks are forbidden from directly owning more than $5 \%$ of a non-financial company.

${ }^{26}$ See "From Bad to Worse," The Economist, 9/23/00.

${ }^{27}$ Norwegian law forbids a bank from directly owning a stake in a non-financial firm larger than $1 \%$ of the bank's assets and the practice of pyramiding and cross-holding is relatively uncommon. Approximately $15 \%$ of the shares on the Oslo Stock Exchange are cross-held (Bøhren and Norli (1997)), compared with 40\% of shares in Japan (Fukao (1998)).

${ }^{28}$ Sources: Bøhren and Ødegaard (2000) and Tokyo Stock Exchange 1999 Share Ownership Survey. 